University of Louisville

ThinkIR: The University of Louisville's Institutional Repository

Electronic Theses and Dissertations

3-1947

\title{
Tragic implications of man's frustration by society in three of Dreiser's novels.
}

Susan Mae Robinson

University of Louisville

Follow this and additional works at: https://ir.library.louisville.edu/etd

Part of the English Language and Literature Commons

\section{Recommended Citation}

Robinson, Susan Mae, "Tragic implications of man's frustration by society in three of Dreiser's novels." (1947). Electronic Theses and Dissertations. Paper 2062.

https://doi.org/10.18297/etd/2062

This Master's Thesis is brought to you for free and open access by ThinkIR: The University of Louisville's Institutional Repository. It has been accepted for inclusion in Electronic Theses and Dissertations by an authorized administrator of ThinkIR: The University of Louisville's Institutional Repository. This title appears here courtesy of the author, who has retained all other copyrights. For more information, please contact thinkir@louisville.edu. 


\title{
UNIVERSITY OF LOUISVILLE
}

\section{TRAGIC IMPLICATIONS OF MAN'S FRUSTRATION BY SOCIETY IN THREE OF DREISER'S NOVELS}

\author{
A Dissertation \\ Submitted to the Faculty \\ of the Graduate School of the University of Loulsvilie \\ In Partial Fulfillment of the \\ Requirements for the Degree \\ of Master of Arts
}

Department of English

$\mathrm{By}$

Susan Mae Robinson

Year

1947 
NAME OF STUDENT: SUSAN MAE ROBINSON

TITLE OF THESIS: TRAG IC IMPLICATIONS OF MAN'S FRUSTRATION

BY SOCIETY IN THREE OF DREISER'S NOVELS

APPROVED BY READING COMMITTEE COMPOSED OF THE

FOLLOWING MEMBERS :

Morris Bein

Ernest C. Hassold

W. C. Mallalieu

NAME OF DIRECTOR:__ Morris Bein

DATE: Tirmeh 15, 1947 
TABLE OF CONTENTS 
TABLE OF CONTENTS

PAGE

FRONTISPIECE • . . . . . . . . . . . . . . . . . 11

PREFACE - . . . . . . . . . . . . . . . . . 1 IV

PART ONE

GHAPTER

I. SOCIAL AND INTELLEC TUAL BACKGROUND

OF DREISER'S TIME • • • . . . . . . . •

II. DREISER'S PARTICULAR BACKGROUND AND

HIS ATTITUDE TOWARD LIFE • . . . . . . .

8

PART TWO

CHAPTER

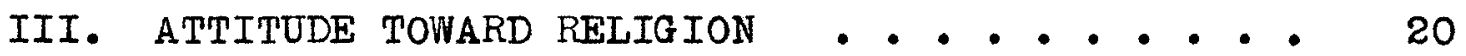

IV. ATTITUDE TOWARD SEX . . . . . . . . . . 54

V. ATTITUDE TOWARD ECONOMIC STATUS . . . . . 80

VI. CONCLUSIONS • . . . . . . . . . . . . 95

EIBLIOGRAPHY . . . . . . . . . . . . . . . 102 


\section{FRONTISPIECE}

\section{ALL IN ALI}

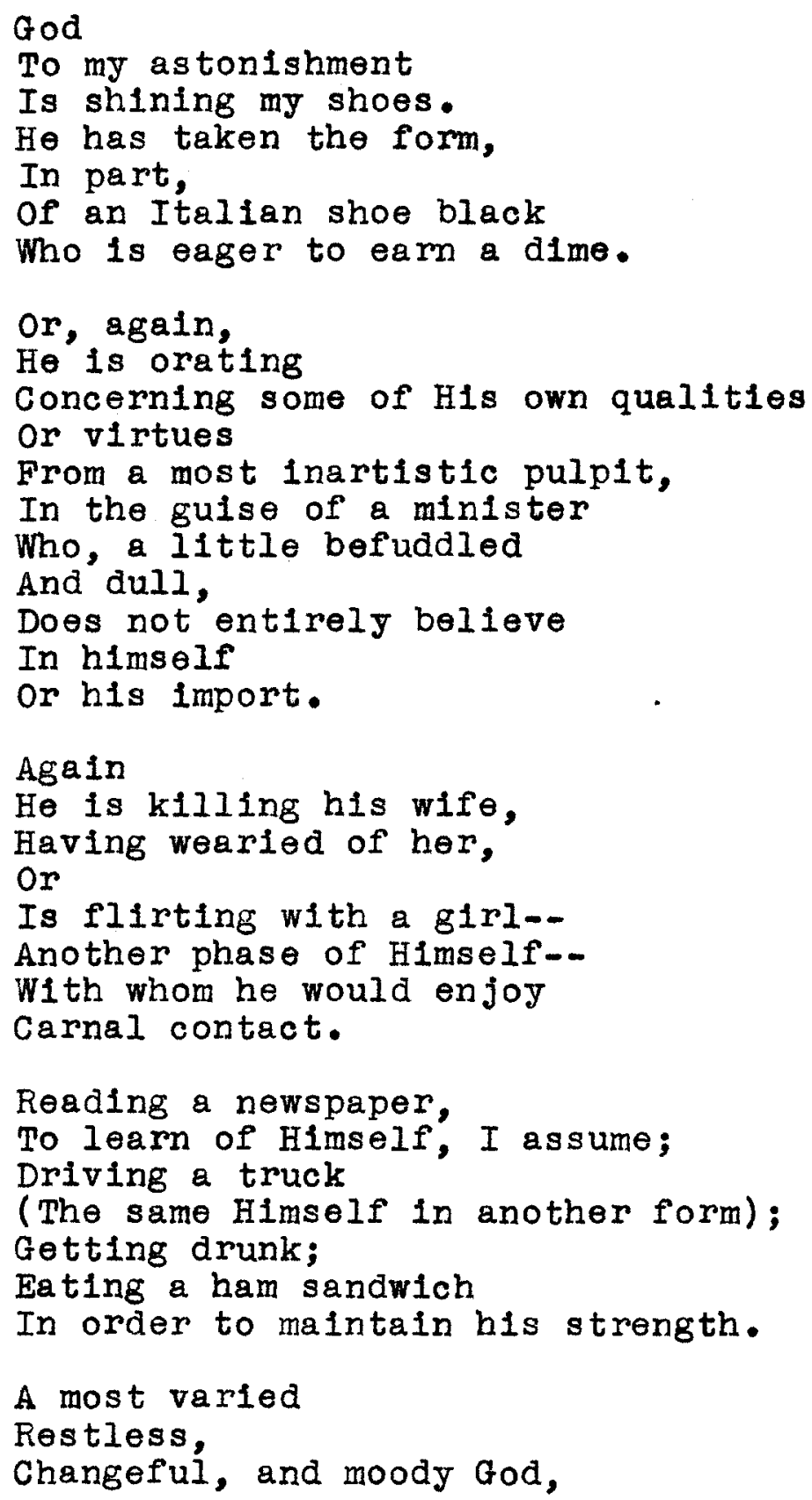




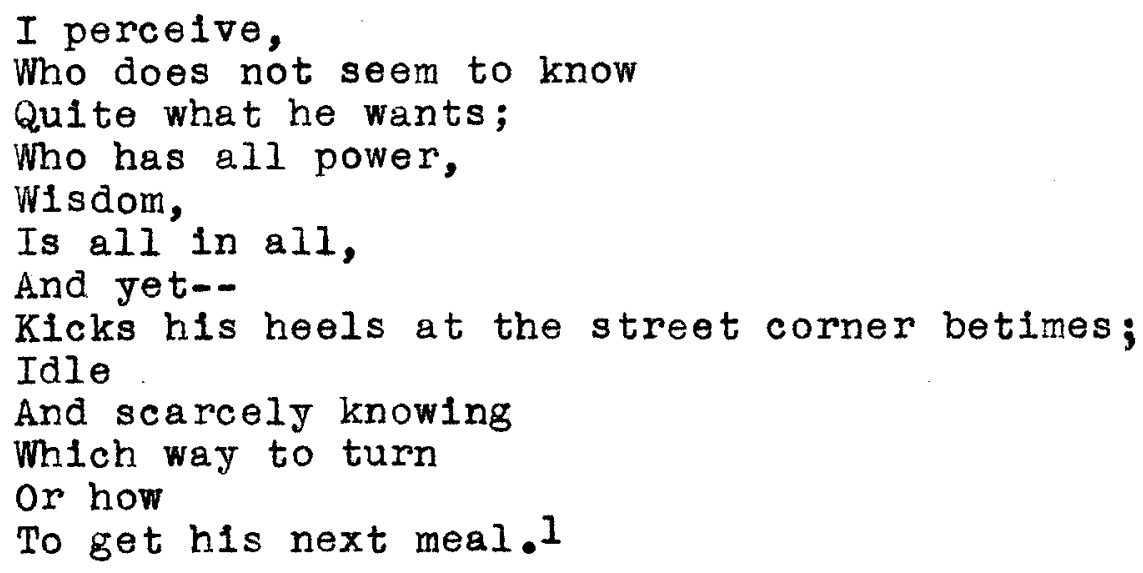

1 Dreiser, Theodore, "What I Belleve", The Forum, IXXXII, p. 279 . 


\section{PREFACE}

The purpose of this paper is to examine three of Dreiser's major novels in order (I) to show that his philosophy of life is exemplified in his fiction and (2) to determine whether or not his ideas undergo any change. The three novels chosen for this study are The "Genius", An Americen Tragedy, and The Bulwark, because they cover a span of American life, as Dreiser saw 1t, from the time of his greatest productivity until his death--a period of thirty years. The first part of the thesis will contain: (1) a general background of the period of which Dreiser is a product and (2) Dreiser's particular background and his attitude toward life.

The second part will comprise an analysis of the novels under study, which are to be considered under three major headings: (1) attitude toward religion, (2) attitude toward sex, and (3) attitude toward economic status. 
PART ONE 
SOCIAI AND INTELLECTUAL

BACKGROUND OF DREISER'S TIME 
SOCIAL AND INTELLECTUAL BACKGROUND OF DREISER'S TIME

The first section of this paper is concerned with sketching a background for an analysis of three of Dreiser's novels, namely, The "Genlus", An American Tragedy, and The Bulwark. It consists of two chapters: Social and Intellectual Background of Dreiser's time, and Dreiser's Particular Background and His Attitude Toward L1fe.

The purpose of the first chapter is to give a general Idea of the changes which were taking place in America from 1860 to 1920, the period in which Dreiser was born and in which he played such a vital part for the first fifty years of his Iffe. Necessarily the sources used for this chapter have been secondary.

The America into which Dreiser was born in 1871 was changing rapidly both technologically and intellectually. It was an epoch in which ". . another world of thought and experience was rising above the horizon--a world in which the divinities were science and the machine--that was to disintegrate the traditional society of the dispersion and reshape the plastic materials in new forms."I

I Parrington, Vernon Louls, Main Currents in American Thought, Harcourt, Brace and Company, Ne Tork, 1930 , VOI. III, p. 189 . 
The drift outward to new land where the individual was free, and the anarchistic attitude which was the heritage of the American and French revolutions were ending.

The industrial revolution, bringing in its wake large cities, drawing men from the farm to the factory, brought great intellectual change. The nature of this intellectual transformation brought about by the growth of science and technology is summed up in Parrington's work: ". . this revolutionary work of the machine was hastened by the new spirit of science that spread silently through the land, effecting a revolution in men's thinking as great as the machine was effecting in men's lives. . ."2 The newly discovered laws of science created a new philosophy. They disintegrated the old theological cosmos and brought into question all the traditional falths-political, social, theological, and philosophical.

Between 1870 and 1900 there were two contradictory phases in the movement of thought: ". " the extension of the philosophy of the Enlightenment, and the final rejection of the Enlightenment in consequence of a more rigid application of the law of causality in the light of a more mechan- 
istic universe." 3 In the earlier part of the period, biology was interpreted in the light of eighteenth century philosophies. With the substitution of physics for chemistry, a more sombre mood resulted--a mood that substituted a mechanistic conception for the earlier romantic and teleological ideas of progress. "The great changes came swiftly because the machine had prepared the way; . . with the revolutions in economics and industry, with the rise of urban society, the mind of America was making ready for the reception of science and the realism that was eventualiy to spring from science." 4

In the light of this new evolution of thought, the old theological conception of a world of good and evil and a beneficent providence faded into insignificance. The emphasis was now brought to play upon the whole rather than the parts. "The individual, thus concelved of socially and politically, was no longer an isolated, self-determining entity, but a vehicle through which was carried the stream of Iffe - . He was a portion of the total scheme of things, tied by a thousand invinclble threads to the encom-

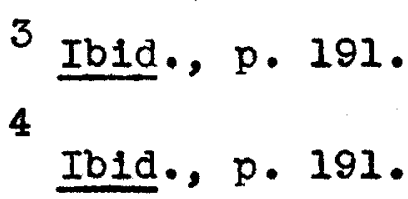


passing whole. From the parts to the totality, from freedom to determinism--such was the drift of thought that science la1d upon us and from which there was no easy escape." 5

Parrington aptly describes the American scene immediately preceding the publication of Dreiser's first novel:

So late as 1893 . . American realism was still unlike in temper those somber etchings, burnt into dark patterns by the caustic acids of European experience, that came from the hands of the Russian, French and German naturalists--sketches that in their b1tter gloom seomed/tragically untrue to the homelier experiences of America. In appraising such a difference in temper Howells ascribed it to the gulf that separated America well-belng from the poverty and injustice of European socleties... Whoever should strike a 'note so profoundly tragic in American fiction' as was struck in Dostoevsky's Crime and Punishment, he asserted in 1891, 'would do a false and mistaken thing' . . . But while Howells was thus summing up the achievements of American realism... he was in fact writing the history of a past phase... Young men born in the early seventies, when Mr. Howells was entering upon his new realistlc studies, were coming to intellectual maturity in a very different age; a new sclence and a consolidating economics were creating a somber temper that was eventually to produce in An American Tragedy, a story not greatly unlike that Russian tale which Mr. Howells, a short generation before had pronounced impossible to American experience. Stephen Crane and Frank Norris and Theodore Dreiser were the intellectual children of the nineties, and their art was a reflection of that sober period of American disiliusion ....

The conclusions of physics ravaged the orderliness of blological evolution with its doctrine of organic growth

$$
\begin{aligned}
& 5 \text { Ibid., p. } 192 . \\
& 6 \text { Ibid., p. } 316 .
\end{aligned}
$$


and continuity. "The universe that unfolded itself to chemistry and physics was vaster and colder than blological evolution, with its doctrine of the conservation of energy, had imagined-a vibrating mechanism shot through with energy, that revealed itself in action and reaction, impersonal, amoral, dwarfing all the gods dreamed of hitherto; a universe in which generations of men have shrunk to a pin point in limitless space and all teleological hopes and fears become the emptiest of futil1ties. ${ }^{7}$ The conception of determinism finally recelved wide acceptance; no longer hampered by teleological influences, It shaped the new intellectual attitudes toward life. "As this mechanistic conception found lodgement in minds prepared by a mechanical economics, a benevolent egocentric universe became unthinkable... The intellectual backgrounds were thus preparing for a gloomier realism/than Howell's or Garland's, a realism that took its departure from two postulates: that men are physical beings who can do no other than obey the laws of a physical universe; and $i m$ that in the vast/differentism of nature, they are inconsequential pawns in a game that, to human reason, has no meaning or rule... Dreiser was the first spokesman of a later America once more fallen within the shadow of the

$$
7 \text { Ibid., p. } 317 \text {. }
$$


pessimism that springs from every centralized soclety shut up within the portals of a static economics; that dwarfs the individual and nullifies his will, reducing him from a child of God to a serf." 8

While this intellectual revolution was taking place, America was rapidly changing physically. The country was growing by leaps and bounds. "From 1850 to 1910, we built half as much rail road mileage as all the rest of the world. Population trebled. This fact stands alone in the data of vital statistics. Yet even more remarkable were the alterations of human activity. The number of clty dwellers increased $3 \frac{1}{2}$ times faster than the population; the number of wage-earners, 2 times faster; clerks, salesmen and typists, $6 \frac{1}{2}$ times faster; banks, 7 times faster; corporations,

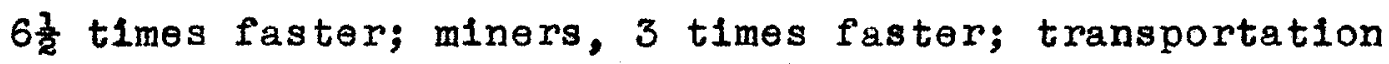
workers, 20 times faster; and the number of independent farmers decreased." 9

Private capital was no longer forced to struggle along by itself reaping what benefits it could from its own power. Because of the creation of sales hitherto undreamed

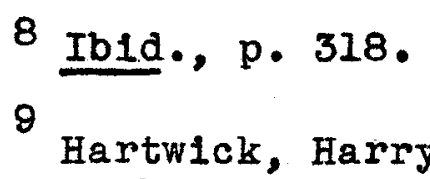
American Book Company, New York, 1934, p. $\frac{\text { Tor }}{94}$ 
of, our American banks saw fit to extend credit for enormous sums on the strength of future business $X$ The day of the multi-millionaire was at hand. And thus we find Garret Garret saying: Modern business derives from three passions, in this order, namely: the passion for things, the passion for personal grandeur, and the passion for power." 10

It was this kind of a world into which Dreiser was born; it was in the midst of this period of tremendous expansion that he lived and made his observations. Harlan Hatcher has sald: "Had some farsighted person deliberately set out to fashion a man for the important job of novelist to America in transition from the post-Civil war into the modern age, he could hardly have brought more adequate experience into the confines of one man's Iife."11

10 Rascoe, Burton, Theodore Dreiser, Robert M.McBride, New York, 1925, p. 5.

11 Hatcher, Harlan, Creating the Modern American Novel, Farrar and Rinehart, New York, p. 35 . 
DREISER'S PARTICULAR BACKGROUND AND HIS ATTITUDE TOWARD LIFE 
DREISER'S PARTICULAR BACKGROUND AND HIS ATTITUDE TOWARD LIFE

Born in Indiana in 1871, Dreiser lived in various midwestern small towns and cities until his early twenties. His father was a religious fanatic whose economic fallure was in large part due to this fanaticism. Young Dreiser was taught the ordinary, rigid moral ethic which prevailed at that time. He says:

Because my father was a Catholic and I was baptized in that falth, I was supposed to accept all the dogma, as well as the legends, of the church as true. In the life about me I saw flourishing the Methodist, the Baptist, the United Brethren, the Christian, the Congregationalist, the whatnot churches, each representing according to its adherents, the exact historic and truthful development and interpretation of Ilfe or the world. As a fourteon or fifteen year old boy I listened to sermons on hell, where 1t was, and what was the nature of its torments. As rewards for Imaginary good behavior I have been given colored picture cards containing exact reproductions of heavent Every newspaper that I have ever read, or still read, has had an exact code of morals by the light of which one can detect at once Mr. Good man or Mr. Bad man and so save oneself from the machinations of the latter.l

Because their father demanded it, the children were all sent to Catholic parochial schools where they were taught nothing concerning the sciences and the arts or concerning

1 Dreiser, Theodore, Hey-rub-a-dub-dub, Boni and Liveright, New York, 1920, p. 253. 
Iife 1tself. Dreiser explains that as a boy he was oppressed and delayed in every way by the dogmatic and always threatenIng dominance of the Catholic church and school, and says that it was the seeds sown here that finaliy allenated him from the Church. Equipped with a naturaliy inquisitive and open mind which rebelled against the dogmas that would not permit the mind to operate freely, he later renounced all religions. Dreiser's education, as far as formal schooling is concerned, was very limited. As prevlously stated, his experience in the Catholic parochial schools was more religious than educational. He did, however, spend one year at the University of Indiana, but it avalled him little. He was more interested at this time in women and beauty and the desires of the flesh. He craved the companionship of beautiful girls, the pleasures and revelries of college dances, all of which he was denied because of a lack of money, clothes, and social standing. These general impressions of college life he took away with him, but, as he says, 11ttle knowledge. In the last chapter of Dawn, which he devotes to a discussion of education, he refers to books as alds to observation. He says, "Personal observation and deduction were far more valuable to me than any book. 2

\footnotetext{
2 Dreiser, Theodore, Dawn, Horace Liveright, New York 1931, p. 589 .
} 
The extreme poverty which his family experienced in Terre Haute and Evansville created in Dreiser a yearning for all he did not have and caused him to wonder at a social scheme which excluded so much of what one wanted in Iife.

The 1mmorality of his brother and sisters which brought the Dreiser family into social alsgrace "drove home to Dreiser quite definitely not only the physical results of sex contact but more interesting still, the chill resentment, or at least evasive dread, which failure to conform to socielly accepted arrangements invariably evokes in those who, willingly or not, bow to the convention which inwardly they may condemn." 3

Drelser's early sexual urges were never satisfied because of his feeling of a lack of physical attractiveness and an exaggerated idea of his own impotency. A fear of his own Inadequacy robbed him of the courage which other boys had in the presence of girls; and the natural, easy manner of these boys with the opposite sex was a source of constant envy to him. In Dawn he describes an adventure which occurred while he was attending Indlana University. He was persuaded to accompany a boy and two girls to Louisvilie on a weekend party which resulted in a most embarrasing situation for him.

3

$$
\text { Ibid., p. } 264 \text {. }
$$


While the other couple enjoyed the intimacy of their bedroom, he sat with his girl in one of the "hotel parlors" and made a feeble attempt to "hold her arm or nibble feebly at her fingers". This experience left Dreiser meditating over his defeat and shame and led him to resolve "never, never, never to accept another girl invitation from anyone, since obviously only led to such torturesome and self-belitting things as had but now occurred." 4

Dreiser's personal experience with marriage was short-lived. He met and fell in love with a school-teacher from the country regions of Hissourl (Miss W-, five years his senior, as he refers to her in his autoblography) while he was working for St. Louls newspapers; but, unable at that time to marry, he put off his "perilous adventure until after the first flare of love had thinned into the pale flame of duty." It was in New York many years later that they were finally married "and with what results you may eventually suspect." 5 This rather bitter personal experience combined with his observations of others thrown into the same institution led Drelser to look upon merriage as something doomed to

4 Ibid., p. 439.

5 Dreiser, Theodore, A Book About Myself, Bonl and Liveright, New York, 1925, p. 502 . 
inevitable failure except in those rare instances where two associated and compatible temperaments are brought together each without the trend of mind which leads to varietism.

Referring to his own marriage, he explains that it was one of those cases where two people temperamentally unsuited were "completely lost in the grip of a passion that subsequently proved detrimental." In view of her conventional ideas about marriage and his "variable tendencies" and his "naturally freedom-loving point of view" it was unfortunate that they ever met. After his unhappy venture in matrimony, he expresses the following opinions concerming this institution:

- - the monogamous standard to which the world has been tethered much too harshly for a thousand years or more now is entirely wrong . - . It is a product, I suspect, of intellectual lethargy or dullness, a mental incapacity for individuality. 6

- - the trouble with marriage is that in its extreme interpretation it conflicts with the law of change,... . and hegnce suffers a severe and seemingly destructive defeat."

Dreiser's early attempts to make a living opened up new avenues of observation and experience for him. In chicago he worked as a laundry collector, laborer in a foundry, and

6

Ibid., p. 326

7

Dreiser, Theodore, Hey-rub-a-dub-dub, p. 217. 
real estate salesman. These jobs brought him in contact with all kinds of people, from the poorest on Halstead Street to the wealthiest in fashionable homes on the west side of Chicago, the result of which produced periods of depression and longing for wealth and luxury and a recurring consclousness of the wide gap between classes.

He found himself constantly making comparisons, weighIng values. Mingled with his admiration for the strong and the successful was a profound pity for the poor and underprivileged, who, as he saw, 1t, had no chance to succeed. Yet he had no solution for them and was unwliling to "accept any suspecting even then that man was the victim of forces over which he had no control." In A Hoosier Hollday, he says:

Life was persistently demonstrating to me that self-interest and only self-interest rules--that strength dominated weakness. . . I was taught in the schools - - that democracy is a great success and never to be upset by the cunning and self-interestedness of wily and unsc rupulous men. - and that Christian ideal was right and true, and that it really prevailed in life.... Actually, I went into life. . believing largely in all this, only to find by degrees that this theory has no relationship to the facts.8

And so Dreiser, while he was still in his twenties, took on the quality of a disillusioned idealist. Life, to him,

\footnotetext{
8 Dreiser, Theodore, A Hoosier Holiday, John Lane Company, New York, 1916, pp. z79-280.
} 
was all wrong because it was not what he had been taught to belleve it was. He began seeking for a solution to life which he termed a "desperately subtle and shifty thing".9 He got a Job with a Chicago newspaper, and his favorite question to those whom he interviewed was "what did they think of life, 1ts meaning." 10 As he saw it, "the great business of 1 ife and mind was Iife." Il

Later, when he wrote for St. Louis, Pittsburgh, and New York newspapers, Drelser continued to study and observe Iife in each of these respective cities which "enclosed (in Browning's phrase) 'a world of men', men in streets and factories, courthouses and prisons, stock exchanges and hotels, in banks and brothels, lodges, 'private' offices and bars. - Each growing city in America as Dreiser saw it was a battle field, and the men within 1t, moved by economic and social forces greater than themselves, waged war side by

\footnotetext{
9 Dreiser, Theodore, A Book About Myself, p. 42. 10 Ibld., p. 150

11

Dreiser, Theodore, Life, Art and America, The
} Diamond Press, New York, 19i7, p. 7 . 
side and against each other."12 Morals, he discovered, were very little connected with success or reputation in the modern world. Freedom of speech and of the press were myths.

Then in New York and Philadelphia be began to read Spencer and Huxley and found, he says,". . that all I deemed substantial--man's place in nature, bis importance in the universe, this too, too solid earth, man's very ldentity save as an infinitesimal speck of energy or a 'suspended equation' drawn or blown here and there by larger forces in which he moved quite unconsciously as an atom--all questioned and dissolved into less understandable things ... Man was a mechanism, undevised and uncreated, and a badly and carelessIy driven one at that... W1th a gloomy eye I began to watch how the chemical--and their children, the mechanical-forces operated through man and outside him, and this under my very eyes... Sulcides seemed sadder since there was no care for them; failures the same."13.

Dreiser continued to observe the actions of men and to ponder over his place in the universe until he fully developed a strong sense of the tragedy of Iife. Dreiser sets forth

12 Gregory, Horace, In the Large Stream of American Tradition, Weekly Book Review, New York Herald Tribune, New York, March 24, 1946, pp. 1-2.

13 Dreiser, Theodore, Hey-rub-a-dub-dub, pp. 457-458. 
his own views in a chapter titled "The Essential Tragedy of

\section{Life" in Hey-rub-a-dub-dub:}

But aside from this most effective illustration of the essential nothingness of man (the scientific) is his plain individual weakness here and now as contrasted with his mass 1deals and the huge vanity or tendency toward romance which causes him to wish to seem more than he realiy is or can ever hope to be. For plainly every life, in the last analysis. . however successful from a momentary analys is it may appear, is a failure. We hear of that curious thing, 'a successful $11 f^{\prime}$ '. It is in the main a myth, a self-delusion. How could there possibly be success for a watery, bulbous, highly limited and specially functioned creature, lacking (in the case of man for instance) many of the superior attributes of other animals--wings, a sense of direction, foreknowledge and the like--and manufactured every forty years by hundreds of millions.... To me the most astonishing thing in connection with man is this same vanity or power of romanticising everything related to himself, so that whereas in reality he is what he is, a structure of brief import and minute social or any other form of energy. . . still he has this astonishing power of viewing himself as a tremendous force in himself, a god, a hero, an enduring and undying figure of glory and beauty-as significant almost as the creator himself, in whose image and likeness he is supposed to be made . . . For individuals are never masters in any remarkable way. They merely and at best borrow or direct the energies of many, and in the main to no important result to themselves. A Napoleon slaves and starves to the end that he may die on St. Heleng and bring considerable profit to many who never heard of him and care not at all. A Caesar tolls endlessiy at the organization and the development and preservation of Rome, only to be stabbed to death in his fifty-sixth year practically unrewarded. A Hannibal slaves for Carthage, enduring endless hardships, only to die by his own hand. The category might be extended inderinitely. And yet the world is full of the laudations of the powers of men, the1r satisfactions, their vast, vast rewards and glories; while so many decayed steles and temple doorways, and data unending, bear testimony to their utter material and subsequent spiritual futility. 14

$$
14 \text { Ibid., pp. 242-244. }
$$


This tragic sense of Dreiser's is, then, really a protest against the new order which he accepts because it has been forced on him both by scientific rationality and by his own observation that this is a dog-eat-dog world. He found, according to Parrington, that:

(1) The world is without reason or meaning to us. Why we are here and to what end is unknowable. (2) Men are like chemical compounds existing in a world where they play about like water-flies, skipping restlessiy and unintelifgently as their legs drive them, whom the universe in 1ts vast indifference suffers for a time. (3) Men divide into the strong and the weak; not the good and the bad. The will to power, the desire for pleasure, drive men on their courses. What restrains? Moral codes and social conventions, often useful, of ten harmful. (4) Hence the profound need of sympathy and mercy.15

According to Hartwick:

Dreiser's idea of tragedy is Shakesperian, not Greek. His Clyde Griffiths is a moral coward and weakling, instead of a hero in the Athenian sense; he is a victim of his environment. The criminal, as Dreiser emphasizes, cannot be held responsible for his misdeeds. He is the product of forces beyond his control, an othello, not an Oedipus punished for the dellberate transgression of an ethical law; he is broken on the wheel not because he deserves it, but due to cosmic accidentia. Shakespeare's tragedies are 'fortultous calamities!; whose characters are often the innocent frauds of chance; whereas in the Greek, tragedy was a just dispensation of the gods for an infraction of their code. 'As flies to wanton boys,' sald the Bard, 'are we to the gods; they kill us for sport.' But Dreiser's true complaint is not against the 'gods'; It is aimed at human soclety that tries to polarize the natural currents of Iife. In common with

15

Parrington, Vernon Lou1s, op. c1t., p. 355. 
Nietzsche he believes that man is contaminated by regulations, that he is 'boyond good and ev11'.16

It is in his understanding of human fatality that Dreiser holds his place in the tradition of the great nineteenth century novelists. ${ }^{17}$ T. K. Whipple berates Dreiser for his clumsy style of writing and gives him credit only as a social historian of his period. ${ }^{18}$ on the other hand, H. L. Mencken believes that it is Dreiser's conception of tragedy which makes him great, and he has this to say:

The struggle of man as he [Dreiser] sees 1t, is more than impotent; it is gratuitous and purposeless. [H1s work]. - is not only brilliant on the surface, but mysterlous and appealing in its depths. One swiftly forgets his intolerable writing, his mirthless, sedulous, repelient manner, in the face of the Athenian tragedy he instills into his seduced and soulsick servant girls, his barbarlc pirates of finances, his conquered and ham-strung supermen, his wives who sit and wait... Here precisely is Dreiser's departure from his fellows. He puts into his novels a touch of the eternal Weltschmerz. They get below the drama that is of the moment and reveal the greater drama that is without end. They arouse those deep and lasting emotions which grow out of the recognition of elemental and universal tragedy. His alm is not merely telling a tale; his aim is to show the vast ebb and flow of forces which sway and condition human desting 19

16 Hartwick, Harry, Op. c1t., p. 91.

17 Gregory, Horace, op. c1t., pp. 1-2.

18 Whipple, T. K., Spokesmen, D. Appleton and Company, New York, 1928, pp. 70,71.

19 Mencken, H. L., A Book of Prefaces; New York, Alfred A. Knopf, 1917, pp. 89,97 . 
This sense of tragedy then, the inevitable frustration of man, is what I Intend to show in the three Dreiserian novels chosen for this study. In this chapter I have reviewed Dreiser's personal experiences as he related them in his autobiographical accounts, and I have shown how his attitude toward Iife, which is essentialiy tragic, was colored by his participation in the period in which he lived. Now it is my purpose, in the second part of this paper, to show that, no matter what the force of religion upon him, what the power of inner compulsion within him, which for Dreiser is mainly sexual, or what his economic status, the individual always loses in the end. I shall treat three diverse characters: a man of flerce drive and much talent; a man of ordinary drive and little talent; a man of serene temperament with little drive and considerable talent. These characters are the protagonists in The "Genius", An American Tragedy, and The Bulwark--the three of Dreiser's novels to be considered in chapters three, four, and five. 
PART TWO 
ATTITUDE TOWARD RELIGION 


\section{PART II}

CHAPTER III

\section{ATTITUDE TOWARD REIIGION}

In this chapter, I am going to show that Dreiser uses religion in two different ways: (1) as an individual solace to satisfy a need which most people seem to feel, and (2) as the embodiment of social codes of conduct, usually dictated by the ruling classes, designed to keep the llower classes' in check and thereby serving as a major focal point in frustrating the drives of individuals.

As evidence that Dreiser believes that morality has no bearing on man's career, I shall show that the degree of religion professed or actually felt by the individual has no effect on the inevitable crack-up of the lives of the principal characters treated here.

I showed, in Chapter II, how Dreiser's early religious experience caused him to renounce all religions. Now I shall give a more detalled account of these experiences in order to show their relation to Dreiser's treatment of his characters in regard to religion. of the atmosphere which dominated his home, he has this to say:

Cathollcism, in our family, was the true religion; 
some form of protestantism in the homes of all our neighbors. The darkness and intolerance in which they were hold An atheist was a criminal. Anyone who doubted that Christ died on the cross to save all men or that men were truly saved thereby, or that there was a specific heaven, a definite hell, and so forth was a scoundrel, a reprobate, a lost soul. Just how people were to IIve and die had all been fixed long before. There were no crimes greater than adultery, atheism, and theft . . . I picture this atmosphere because some phases of it were at times so stern and destructive.1

As previously stated, his father was a fanatic on the subject of religion. His mother, although born a Mennonite, seems to have been quite passive and dominated by the 1deas of the father. Concerning his father, he says:

I have described my father as a religlous enthusiast. At that time he was a morose and dour figure.... One of his worst phases was the conviction that there was refuge in religion, more and more self-humiliation before a creator who revealed himself only through the forms and ceremonies of the Catholic Church. He believed implicitly that the least neglect or infraction of such forms and ceremonies as were ordered by the Church was sufficient to evoke disfavor or at least neglect on the part of the universal ruler. This being true, the rather indifferent religious conduct of his wife and children was sufficient to convince him that they were evil to a degree and in need of driving.2

This attitude of his father pursued Dreiser throughout his early years. When the family moved to Evansville:

1

Dreiser, Theodore, Dawn, p. 15.

2 Ib1d., p. 25. 
For my father, the moment he appeared on the scene, and with his usual zeal for the welfare of our souls, sought out the nearest German Catholic church and forthwith enrolled the entire family as communicants. 3

And when they moved to chicago:

Nothing in Chicago, therefore, concerned him quite as much at this time as the whereabouts of a Roman Catholic church and school.4

And again when they had moved to little Warsaw, Indiana:

'Look at these schools,' he went on to me once, his face a study in impotent rage, bitterness and grief. 'No Bible in them, or if there is one, a protestant Bible, gotten up by that scoundrel and full of lies ! No separation of the boys and girls as there should be in any well-regulated state of society! The shamelessness of these Amerlcan children. Boys and girls together. Terrible. No vow-bound, God-fearing nuns or priests to curb them, but silly girls, their heads full of beaux, to teach these innocent children. God will visit his wrath on such a country. Wait and see! Wait and see!'5

Dreiser's reaction to this influence was rebelilion.

He came to view organized religion as the embodiment of a public morality designed to frustrate the primary urges of the Individual and as a tool utilized by the powerful ruling class to hold the masses in check:

3 Ib1d., p. 127.
4 Ib1d., p. 166.
5 Ib1d., p. 203. 
The best interpretation of religion that I have ever heard is that found in St. James $1: 27--"$ Pure religion and undefiled before God and the Father is this: To visit the fatherless and widows in their affliction"--not when they are prosperous mind youl--" and to keep himself unspotted from the world." And the best method of worshipping God--which is certainly an integral portion of reIigion--is found in John 4:24--"God is a spirit, and they that worship Him must worship Him in spirit and truth." or let us say sincerity. Now if these... things mean anything. . . forms and methods of procedure ought not to count for much. There is no precise ritual prescribed in the New Testament.. . the method, outside of a certain generosity of soul . . has usually been left to the individual. And it is only because powerful and wholly practical and political organizations have usurped the religlous business, gone, wholesale into the business of electing officers, or heads, bullding churches, collecting money and using the same not merely as a means of bare subsistence but to erect and enjoy power and the panoply of the same, and to direct the masses as they will, that they have won to the point, in pride and strength. where they have become able to harry and destroy lesser organizations or individuals trying to address God or nature direct. 6

In thinking about an instance of sexual irregularity

which happened in an office where he was working, Dreiser identified the code of an organized religion with a social code. He said in regard to the fact that a man had been unfaithful to his wife:

My father and the Catholic Church would emphatically say wrong - - . Personaliy after due thought I could not see it that way. I found myself siding with the individual and the passions which nature had created as opposed to the hard and fast rules of society. 7

\footnotetext{
Ib1d., pp. 473,474.

7 Ib1d., p. 551.
} 
As for the effect of actual religious feeling on the individual, Dreiser says :

I would say that it is a bandage that man has invented to protect a soul made bloody by circumstance; an envelope to pocket him from the unescapable and unstable ilIimitable. We seek to think of things as permanent and seo them so. Religion gives life a habitation and a name apparently--though it is an illusion . . . Yet the need for religion is impermanent, like all else in life. As the soul regains its strength it becomes prone to the old illusions. 8

These two ideas of religion, that is, as a solace to the individual in time of need and as an embodiment of the morals or ethic of society permeate Dreiser's novels. H1s characters seek that solace, but they get it only in varying amounts according to their own personalities. At the same time they are always running head on into the social embodiment as it counters their own inner urges.

\section{The "Genius"}

The first novel to be considered is The "Genius" because it was written first. Here the treatment of religion is subordinated to the treatment of sex, which will be discussed in the following chapter. Dreiser's preoccupation with religion is, however, apparent in this early novel.

8 Dreiser, Theodore, The "Genius", New York, Bon1 and Liveright, 1923, p. 734 . 
The principal character, Eugene Witla, since he was an artist and a man of thought, devoted some time to abstract thinking, in which he questioned rather seriously the current religlous thought and feeling. In contrast to witla, his wife accepted without question the conventional ideas of her time. When Witla met a crisis, he attempted to turn to religion for solace. He was persuaded to consult an unprepossessing practitioner of the Christian Science falth.

Since he came from a lower middle-class family of the mid-west, Witla had encountered no questioning of the accepted theories of conduct which he heard and saw getting at least lip-service from those about him. However, when he left home and became a practicing artist, his ideas changed, or rather, it should be said, they crystallized. This is best shown by his relationship with his wife, Angela Blue, and her family. "With Eugene convention meant nothing at all, and his sense of evil and good was something which the ordinary person would not have comprehended." 9 on the other hand, "Angela. . had a distinct preference for those who conducted themselves according to given standards of propriety. . Who conformed to the ordinary notions of right and wrong." 10

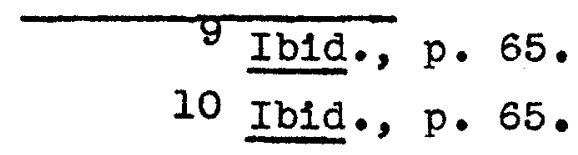


Unfortunately for Witla, he was a man who had some insight into the problem. I say unfortunately because he understood the motivations of those with whom he came into inevitable conflict. He came to understand the "extraordinary demands of some phases of dogma in the matter of religion; the depths of human perversity in the matter of morality; the fact that there were worlds within worlds of our social organism; that really basically and actually there was no fixed and definite understanding of anything by anybody." Il And when be visited Angela's family he could see that any "form or order of society which hoped to endure must have individuals like Mrs. Blue, who would conform to the highest standards and theories of that society, and when found, they were admirable; but they meant nothing in the shifting, subtle forces of nature. They were just accidental harmonies blossoming out of something which meant everything here in this order, nothing to the universe at large."12 The Blue family "obeyed the ten commandments in so far as possible and lived within the limits of what people considered sane and decent." 13

$$
\begin{aligned}
& 11 \text { Ibid., p. } 93 . \\
& 12 \text { Ibid., p. } 118 . \\
& 13 \text { Ibid., p. } 122 .
\end{aligned}
$$


After several years of marriage Witla was greeted by his first crisis. He was unable to produce any work. He met this by a process of self-examination. "Always of a philosophic and introspective turn, this peculiar faculty of reasoning deeply and feeling emotionally were now turned upon himself and his own condition, and as in all such cases where we peer too closely into the subleties of creation, confusion was the result. Previously he had been satisfied the world knew nothing. Neither in religion, philosophy, nor science was there any answer to the riddle of existence. - - He figured Iffe as a grim, dark mystery, a sad, semi-conscious turning aimlessly in the dark . . . God knew nothing . - Malevolence, life living on death, plain violence-these were the chlef characteristics of existence. If one failed of strength in any way, if life were not kind in its bestowal of gifts, if one were not born to fortune's pampering care--the rest was misery. In the days of his strength . . the spectacle of existence had been sad enough: in the hours of threatened delay and defeat lt seemed terrible. - . He did not immediately give up hope. - for months and months he fancled each day that this was a temporary condition."14 Finally, however,

$$
14 \text { Ibid., p. } 251 \text {. }
$$


he suffered a complete nervous breakdown.

After a few years of floundering around he began to recover. He got a job as an outdoor railroad worker. While this was helping him regain his strength, he met a woman who was attracted to him. His wife was living with her parents because he was so poor. His relationship with Carlotta troubled him. She gave him the following advice: "I don't think 1t's so bad. It depends on how you were raised.' There was a system apparently in society, but also apparently it did not work very well. Only fools were held by religion, which In the main was an imposition, a graft and a Iie. The honest man might be very fine but he wasn't very successful. There was a great to-do about morals, but most people were immoral or unmoral. Why worry? Look to your health. Don't let a morbid conscience get the better of you. Thus she counselled, and he agreed with her."15

Many years later, after a phenomenal success in the business world, Witla was again faced with a serious crisis. He wanted a young woman and was prevented from getting her by the conventions which he abhorred. His family iffe was torn up by the roots; his wife died giving birth to a belated child. In this crisis Witla turned to Christian Science. He turned

$$
15 \text { Ibid., p. } 361 .
$$


to this particular creed because his sister had become enamored of it and insisted that it would help him. He began reading some of the scientist's literature. "It 1rritated and, from a critical point of view, amused him. The author talked of the evidences of the five physical senses as worthless, and yet was constantiy referring to and using similes based upon those evidences to illustrate her spiritual meanings. He threw the book down a number of times, for the Biblical references irritated him. He did not belleve in the Bible. The very word Christianity was a sickening jest."16 However, there was something about its spirituality that held him. "It seemed to him to be a wild claim, and yet at the time, because of his natural metaphysical turn, it accorded with his sense of the mystery of life."17

He read at this time a great many "odd philosophic and religlous volumes" in which he learned that "the old prophets were little more than whirling dervishes" 18 and he was finally able to bring himself to believe that God might be a principle, a sort of mathematical principle "like two times two is four." 19

$$
\begin{aligned}
& 16 \text { Ibid., p. } 693 . \\
& 17 \text { Ibid., p. } 694 . \\
& 18 \text { Ibid., p. } 695 . \\
& 19 \text { Ibid., p. } 699 .
\end{aligned}
$$


Later he was persuaded by his sister to visit a practitioner. While he was walting to see her he noticed that the "room was not artistic but rather nondescript, the furniture cheap or rather tasteless in design. Didn't Divine Mind know any better than to present its representatives in such a guise as this? Could a person called to assist in representing the majesty of God on earth be left so unintelligent artistically as to live in a house like this?. Surely this was a poor manifestation of Divinity."20 Then he met the lady who reminded him of "an old print of Mrs. Micawber that he had seen somewhere... So this was Mrs. Johns, he thought... Her hands were wrinkled, her face old. Why didn't she make herself young if she could perform these wonderful cures? Why was this room so mussy? People were such hacks when it came to the art of living. How could they pretend to a sense of divinity who knew nothing of life." After some conversation she asked him to pray. He "sat there trying to think of the Lord's Prayer but in reality thinking of the room, the cheap prints, the homely furniture, her ugliness, the curiousness of his being there."n2I

$$
\begin{aligned}
& 20 \text { Ibid., p. } 703 . \\
& 21 \text { Ibid., p. } 707 .
\end{aligned}
$$


A Ilttle later when his wife lay dying and he was really feeling sorrow, he thought: "There was God somewhere. He was on his throne. These large dark, immutable forces, they were not for nothing. If only she would not die, he would try--he would behave. He would He wouldi"22

After his wife died "during a period of nearly three years all the vagaries and alterations which can possibly afflict a groping and morbid mind were his. He went from what might be described as almost a belief in Christian Science to almost a belief that a devil ruled the world, a Gargantuan, Brobingnaglan Mountebank who plotted tragedy for all Ideals and rejoiced in swine and dullards and a grunting, sweaty, beefy immorality - . He then reached a state not of self-abnegation, but of philosophlc openmindedness or agnosticism. He came to know that he did not know what to belleve. All apparently was permitted." 23

And Dreiser sums the problem up himself. "It is strange, but life is constantly presenting these pathetic paradoxes--the astounding blunders which temperament and blood moods bring about, and reason and circumstance and convention condemn. The dreams of man are one thing, his capa-

$$
\begin{aligned}
& 22 \text { Ibid., p. } 722 . \\
& 23 \text { Ib1d., p. } 726 .
\end{aligned}
$$


city to realize them another. At either pole are the accidents of supreme fallure and supreme success-othe supreme fallure of an Abelard for instance, the supreme success of a Napoleon enthroned at Paris. But, oh, the endless fallures for one success."24

Dreiser's pity for the general situation of man is manifest here. But he exhibits nothing friendly toward reIigion. At best he is glving a dispassionate description of what he sees. The ridiculous light in which he casts and describes the only professional religious person is enough to show that. The utter inability of religion to offer more than the most temporary ald even in the most trying crises proves his opinion of its ineffectiveness.

\section{An American Tragedy}

In An American Tragedy the hero is an ordinary young man (ordinary in the sense that he has no particular gifts or talents) with a peculiar religlous background. H1s parents are presented as kinds of freaks. Dreiser may pity them, yet he depicts them as rather ridiculous characters. At the beginning of the book, the father is described as ${ }_{a}$ most unimportant looking person" 25 leading a forlorn little

24 Ibid., p. 730.

25 Dreiser, Theodore, An American Tragedy, New York, Horace Liveright, 1929, p. 3 . 
group of street religionists. These people attracted public attention in that "various homeward-bound individuals of diverse grades and walks of life, notlcing the small group disposing itself in this fashion, hesitated for a moment to eye them askance or paused to ascertain the character of their work."26 Already at this time twelve years old, clyde Griffiths, "seemed to resent and even suffer from the position in which he found himself. Plainly pagan rather than religious, Iife interested him." 27

The ineffectiveness and the attitude of Clyde's parents are epitomized in the following passage:

As for the parents, they were determined upon spirituallzing the world as much as possible, and once the hymn was concluded, the father launched into one of those hackneyed descriptions of the delights of a release, via the self realization of the mercy of God and the love of Christ and the will of God towards sinners, from the burdensome cares of an evil conscience.28

The boy was constantly disturbed by the position of his parents in the world in which they lived. "The princlpal thing that troubled clyde up to his fifteenth year, and for a long time after in retrospect, was that the calling of his

$$
\begin{aligned}
& 26 \text { Ibld., p. } 4 . \\
& 27 \text { Ibid., p. } 5 . \\
& 28 \text { Ibid., p. } 7
\end{aligned}
$$


parents was the shabby thing that it appeared to be in the eyes of others... It had been obvious that people... looked down upon him and his brothers and sisters for being the children of such parents." 29

clyde at this time had no thoughts on religion. He had a job as bell hop in a hotel in Kansas city; he was proud to be making his own way in the world. Then the automobile accident occurred in which the girl was killed, and he was involved. He had no thoughts of remorse or any feelings of religlous guilt. He merely thought of muning away. Afterward when he had established himself in another city and the affair had blown over, he started to communicate with his mother. She wrote him to "stop and listen to the volce of our Lord" and admonished him to "hold fast to your early teachings." 30 Later in the letter she mentioned a rich uncle who might be able to help him, and Clyde immediately began to plan a means of contact with his wealthy relative.

Later he met this rich uncle who gave him a job in his collar factory. There he met a factory g1rl, who was a "reflection of the religious and moral notions then and there

$$
\begin{aligned}
& 29 \text { Ibid., p. } 10 . \\
& 30 \text { Ib1d., p. } 169 .
\end{aligned}
$$


prevailing, -- the views of the local ministers and the laity in general." 31 They began a relationship which led to intimacy; she became pregnant and, since he did not wish to marry her, he persuaded her to go to a doctor to try to get an abortion performed. Dreiser's description of the doctor and his reaction to the problem presented typified his idea of the social attitudes prevalling at the time. The doctor was

- . the typical and fairly conservative physician of the countryside--solemn, cautious, moral, semi-religious to a degree, holding some views which he consldered liberal and others which a fairly liberal person would have considered narrow and stubborn into the bargain .... In constant touch with all phases of ignorance and dereliction as well as sobriety, energy, conservatism, success. and the like, he was more inclined, where fact appeared to nullify his early conclusions in regard to many things, to suspend judgment betweon the alleged claims of heaven and hell and leave 1t there suspended and undisturbed. [His attitude toward this problem was that] for various reasons connected with his own temperament.. as well as the nature of this local social world, he disliked and hesltated even to trifle with it... And so, although in several cases in the past ten years where family and other nelghborhood and religious considerations had made it seem advisable, he had assisted in extricating from the consequences of their folly several young girls of good family who had fallen from grace and could not otherwise be rescued, still he was opposed to aiding, either by his own countenance or skill, any lapses or tangles not heavily sponsored by others.32

31 Ibid., p. 250.

32 Ibid., pp. 410-412. 
Th1s passage shows Dreiser's perception of the relationship of religious thought to the local mores of the community-the banding together under the guise of religion of local attitudes of opprobium towards those who have violated the social ethic. I shall show in another chapter the causes of these various violations.

Later after clyde has been driven to bring about this girl's death, the following description is offered to prove that she is a good girl: "Her devotion to her parents, her simple ways of living, her modesty, morality, religious devotion--how once the pastor of the local church had sald she was the brightest, merriest, and kindest girl he had ever known."33 Always the church and religion are brought in to depict the feeling concerning local customs.

After clyde was arrested and charged with murdering the girl, his lawyer gave him the following advice: "I don't know whether you are at all religlous, but whether you are or not, they hold services here in the jail on Sundays, and I want you to attend them regularly, that is, if they ask you to. For this is a religious community and $I$ want you to make as good an Impression as you can." 34 Thus Dreiser cynically

$$
\begin{aligned}
& 33 \text { Ib1d., p. } 168 . \\
& 34 \text { Ib1d., p. } 188 .
\end{aligned}
$$


expresses the necessity for conforming to the local mores if one is to survive.

Clyde's mother, when she was informed of his difficulty, immediately turned to her religion. She said, "Let me have the Bible1.. . It was as if in spite of all this, she had been able to retreat into some still, silent place, where for the time being at least, no evil, human 11 l could reach her." 5 This sympathetic treatment of a religious attitude in the mother is sharply contrasted with the description of the freaks who vis ited Clyde in ja1l: "He was constantly being visited by every type of doctor, merchant, yokel evangelist or minister... asking such questions as: 'Do you pray, brother? Do you get right down on your knees and pray?' . Had he made his peace with God?" 36

His jury for the trial is described as ".. With but one exception all religious if not moral and all convinced of clyde's guilt before they sat down." 37

During the trial, Clyde's lawyer, when questioning him about his relationship with the dead girl, asked, "Didn't you know that all men, and all women also, view 1 t as wrong, and outside of marriage unforgivable--a statutory crime?'
35 Ibid., p. 215.
36 Ib1d., p. 219.
37 Ib1d., p. 231 . 
The boldness and ironic sting of this was sufficient to cause at first a hush, later a slight nervous tremor on the part of the audience which Justice Oberwaltzer noting, frowned apprehensively. Why this brazen young cynicl How dared he, via innuendo and in the guise of serlous questioning, intrude such a thought as this, which by implication at least picked at the very foundations of soclety--religlous and moral."38 Dreiser here is taking a side-swipe at the moralists who refuse to recognize that actions are not governed by the social code which is given pseudo-sanction by society.

Clyde was declared guilty by the jury and at this time his mother came to his aid. She was "... middle-aged, homely, religlous, determined, sincere and earnest and with a moving faith in the innocence of her boy . . . A crude and unlettered and yet a convinced figure. The wide flat shoes. The queer hat. The old brown coat. Yet somehow after a few moments arresting in her earnestness and faith and love for her son, and her flxed, inquiring, and humanly clean and pure biue eyes in which dwelt immaterial conviction and sacrifice with no shadow of turning." 39 It was necessary for Mrs. Griffiths to raise money to appeal Clyde's case, so she decided to lecture in varlous churches, appeal for funds in the

$$
\begin{aligned}
& 38 \text { Ib1d., p. } 270 . \\
& 39 \text { Ibid., pp. } 343,344 .
\end{aligned}
$$


Christian cause of mercy.

"However after three weeks of more or less regional and purely sectarian trying, she was compelled to report the Christians at least were very indifferent--not as Christian as they should be." She was regarded as ". . . an exhorter--a secret preacher-one who in deflance of all the tenets and processes of organized and historic, as well as hieratic, religious powers and forms (theological seminaries, organized churches and their affiliations and products--all carefully and advisediy and legitimately because historlcally and dogmatically interpreting the word of God) choosing to walk forth and without ordination after any fashion conduct and unauthorized and hence nondescript mission... And not only that--but according to Clyde's own testimony in this trial, had he not been guilty of adultery with this girl--whether he had slain her or not. A sin almost equal to murder in many minds. Had he not confessed 1t? And was an appeal for a convicted adulterer--if not a murderer.. . to be made in a church. No, -no Christian church was the place for such debate... - It was not morally advisable. It might even tend to implant in the minds of the young some of the details of the crime. Besides. . It was assumed by most ministers that she was one of those erratic persons, not a constituent of any definite sect, or schooled theology, who tended by her very appearance to cast contempt on true and pure religion." She did not appeal to the Catholics because she knew that... "The mercies of Christ as interpreted by the holder of the sacred keys of St. Peter. - were not for those who falled to acknowledge the authority of the Vicar of Christ . . She was at last compelied.. . to appeal to a Jew who controlled the principal moving picture theatre of Utica--a sinful theatre. And from him, this she secured free for a morning address." 40

This is the most drastic indictment which Dreiser makes on organized religion. The absolute repudiation of all professed principles of charity and mercy by their professional advocates is typical of his personal attitude.

40 Ib1d., pp. 358,359 . 
Meanwhile, Clyde, now facing death, has turned toward religion, seeking an explanation for his plight. His mother had persuaded a young non-sectarian minister, Duncan McMillan, to try to help clyde. To clyde, he was "another religionist, of course.. - but arresting and attractive." 41 clyde confessed to him that.. " If only he could win to spiritual peace through prayer he would be glad to do 1 . "42 McMillan talked to him, urged him to ask "the Creator of it all to tell you how and what to do. Don't doubt. Just ask. He will not fall you." Then clyde" . . leaning against his cell door, began to wonder. The creator, his creator . . . Ask and see .... And yet--there was still lingering here in him that old contempt of his for religion and its fruits,the constant and yet frultiess prayers and exhortations of his father and mother. Was he golng to turn to religion now, solely because he was in difficulties and frightened like these others. He hoped not. Not like that, anyway."43

"What followed then was what invariably followed in the wake of every tortured consclousness. From what it dreads or hates, yet knows or feels to be unescapable, it takes re-
41 Ibid., p. 373.
42 Ibld., p. 375.
43 Ibld., p. 376. 
fuge in that which may be hoped for--or at least imagined.. - What did it all mean? Was there a God? Did he interfere in the affairs of men, as Mr. McMilian was now contending?. . Would this mysterlous power be likely to grant aid? - Was he seriously moved to assume that in religion of any kind he was likely to find surcease from his present miseries." After much thought along the above lines, clyde was moved to tell MoMilian that he had meant to kill the girl, but had not actually murdered her, since she died accidentally, although in circumstances which he had brought about.

Finally there came a chance for one last appeal to the Governor to save Clyde's Iife. McMillan went with Mrs. Griffiths and after they had spoken to the Governor, he asked Wckillan direct if there were some clrcumstance which could be cited as mitigating the crime. And McMilian " . . pale and dumb, now gazed at him in return. For now upon his word-upon his shoulders apparently was being placed the burden of deciding as to clyde's guilt or innocence. But could he do that? Had he not decided, after due meditation on clyde's confession, that he was guilty before God and the law? And

44 Ibid., pp. $377,379$. 
could he now for mercy's sake--and in the face of his deepest spiritual conviction, alter his report of his conviction? Would that be true, white, valuable before the Lord? No."45 Just before his execution Clyde wrote a letter statIng that he had found Christ and exhorting other young men to Christian ways. And in his last interview with his mother he sald, "Mama, you must belleve that I die resigned and content. It won't be hard. God has heard my prayers. He has given me strength and peace. 'But adding to himself. 'Had he." 146 With that doubt clyde died.

As an epilogue Drelser again shows the Griffiths family, learning nothing, going about with their street preaching and bringing up another boy as they brought up clyde.

In this book we find Dreiser making a severe indictment of organized religion and the morality for which it stands. Even so sympathetic a character as McMillan lacks that mercy which he is constantly preaching. The profesionally religlous characters are presented generally as ridiculous or hypocritical or both. Only the mother is given truly sympathetic treatment. Religion has certainly not buoyed Clyde up to his fate. We are left in doubt as to whether it

$$
\begin{aligned}
& 45 \text { Ibid., p. } 398 . \\
& 46 \text { Ib1d., p. } 404 .
\end{aligned}
$$


was valuable to him or not. He said 1 t was, and yet in the same sentence, doubted 1t. There is no evidence that religion really helped clyde to accept his fate. He gave lip-service to it to make his mother feel better, but this is for love and not religion.

\section{The Bulwark}

Religion and some of its adherents, for the first time, in The Bulwark receive sympathetic treatment. The whole character and background of Solon Barnes is presented in a kindly though pitying manner. Solon's tragedy comes from his attempt to rear his children in the rigid discipling of his church.

Solon himself was brought up in a strict religious atmosphere. His father was . . Well thought of by his fellow Friends of that region and was personally, as well as religlously acceptable to others.. . In the Barnes home - - the fire of faith was ever alight... Solon and Cynthia, the children, never ate a meal which did not begin with a hush of thanksgiving, and apart from that, no day was ever begun without a family gathering at which Mrs. Barnes read a chapter of the Bible which was followed by a weighty silence. - The social and religious atmosphere as a whole at that time permanently imbued Solon and Cynthia so 
that neither, to the end of their days, ever doubted the truth of the Divine creative presence in everyone, by reason of which all things lived and moved and had their being--the guiding Inner Light or Divine Presence to which everyone could turn in an hour of doubt, or stress, of human confusion and find, ever present there, help and comfort." 47

Rufus Barnes, Solon's father appreclated beauty as ". . something which, because of his early religlous instruction and subsequent reading of the Bible and listening to the spiritual reactions of many Friends, was inherent and inescapable in all the handiwork of the Lord."48 Solon's mother was the sort of person who "found herself not a little religiously and intellectually troubled by the fact that so much ill could come about accidentally when plainly no cruelty or evil was intended." 49

Despite these excellent parents there were some defects to Solon's upbringing .. . "The Frlends' Book of Discipline taught him that romances or novels were pernicious, and as such not rightfully printed, sold, or loaned; they were evil."50 In the course of a difficulty which arose be-

47 Dreiser, Theodore, The Bulwark, Doubleday \& Company, 14 West 49 th Street, Rockefeller Center, New York, 1945, pp.1-3. 48 Ibid., p. 11 .

49 Ibid., p. 18.

50 Ibid., p. 30 . 
tween some workers and townspeople aver the workers' actions which were considered immoral, Solon, "having heard so much of good and evil as words, and having personally seen so little of evil in the form here displayed, could not possibly look back of the surface appearance to the less obvious forces of ignorance, poverty, and the lack of such restraining and elevating influences as had encompassed his own life. He had no least conception of what from childhood has surrounded these ignorant people. He did not know life. Rather to him all those who had sinned were thoroughly bad, their souls irredeemable." 51

Solon's father-in-law was a wealthy banker and also a Quaker. He, "in thinking of his increasing wealth, had finalIy hit upon the--to him--logically acceptable truth that business or trade was a creation of the Lord and intended by Him for the maintenance, education, general welfare, and enlightenment of all of His people on earth . . that he, like all others in life who did anything at all worth while, was a steward or servant under the direction of his creator."52." By following this bellef he was, by the time Solon "encountered him, rich, conservative, religious, and falrly considerate

$$
\begin{aligned}
& 51 \text { Ibid., p. } 35 . \\
& 52 \text { Ibid., p. } 40 .
\end{aligned}
$$


of the welfare of humanity in general."53

When Solon was a young man just starting in business, "Iife, to him--he could not have reasoned it out exactly-was a series of law-governed detalls, each one of which had the import of being directly connected with the divine will. Honesty was a thing commanded by God. Virtue in women was something which expressed the best will and order of the universe. He did not know or understand, of course, any woman who lacked virtue. While he knew there was sin in the world, he was convinced from what he had been taught, that those who were caught in the nets of evil paid dearly in this world or the next, or both. He saw no value in the creeds or sacraments of other religious faiths, though he had a sympathetic regard for all churches as opposed to heathenism. To him the religion of George Fox and John Woolman was the solution of all earthly ills. ${ }^{54}$

Solon married and began to have children. "During these years he exhibited more and more the sobering influence of parenthood, which caused him always to wish and seek to be a light and a guide to them on their uncertain way. Plainly they could all be raised to useful, noble ends, or so he

$$
\begin{aligned}
& 53 \text { Ibld., p. } 83 . \\
& 54 \text { Ibid., p. } 90 .
\end{aligned}
$$


hoped. And so he loved that paragraph in the Book of D1scipline which began: 'In much love to the rising generation', and continuing, 'bear in mind, dear young people, that the fear of the Lord is the beginning of wisdom.' He had no life or gaiety to offer them in the future--his own having been so earnest and simple--but he felt convinced that they should and would be content with what he chose to provide."155

Despite his kindness of heart, Solon began to run into difficulties with his children. They "were becoming, as they grew older, more and more of a problem, for each one in turn could not help being confronted by the marked contrast between the spirit of the Barnes' home and that of the world at large. They were to keep their clothes and their rooms neat, to attend to their religlous duties, observing a time of silence, morning and evening, in which they were supposed to pray or walt for the voice of God to speak in their hearts--in short, they were to follow the rules... consonant.. With the peculiar and deep sense of religlous significance of life which their Quaker falth inculcated."56 However the children observed that they were missing much of the life about them

$$
\begin{aligned}
& 55 \text { Ibid., p. } 109 . \\
& 56 \text { Ib1d., p. } 138 .
\end{aligned}
$$


in which their friends were participating. They became restless. Some of them were observant and enquiring and could not understand their father, thinking him repressive:

To the minds of each of his five children, each with a different point of view, Solon Barnes was somewhat of an enigma. Isobel and Etta loved and admired hlm as a stern, good man, although Etta, particularly as she grew, felt that there was a difference between her father and herself which could never be bridged. Dorothea alone, because of her superficial viewpoint, felt that her father was fairly companionable and a 'dear' because she could get around him. Orville had bullt up an apocryphal notion of his father as a powerful, inaccessible citizen of the world who was to be admired and respected but not really loved except in a filial and perfunctory way. Stewart on the other hand felt something tender in his father which did not concern his strength at all, but which nevertheless, was hidden away deep, like a jewel in a mine, and was scarcely to be reached because of the hard rocks of duty and morality which covered it." 57

Solon did not realize that while be might be able to control their outward conduct he could not control their thinking. So it happened that he came to his first crisis with his family. He caught his daughter Etta reading books which he considered immoral. He questioned her: "ietta, who is to guide thee if thee turns away from the Inner Light? Thee knows my only wish is for thy spiritual growth and thy future happiness. It is my responsibility to show thee the dangers that lie before thee." 158 He then forbade her to read any more

57 Ibid., p. 168.

58 Ibid., p. 200. 
such books or to associate with a girl who he considered was leading her astray. Also he refused to allow her to attend the University of Wisconsin, which she had set her heart on. This sterness on Solon's part caused the girl to steal some of her mother's jewelry and run off to Wisconsin. He was soreIf upset, "but at this point remembered the Inner Light, his refuge amid the ills of this world, and bowing his head, he began a silent but impassioned plea to God to return his child unharmed."59 He went to Wisconsin after her, but was forced to return without her when she absolutely refused to obey him.

A few years later he began to have trouble with his joungest boy, Stewart. The boy was away at school and his father was notified that he was inclined to be wild. Solon was upset again, "for here was another one of his children, in spite of his watchfulness, his reasoning, his prayers, behaving so reprehensibly." This boy however, kept on with his wildness until through unfortunate circumstances he was involved in the death and apparent rape of a girl. Solon was almost crushed by the publicity which so shamed his family. "What was he to do now? Where to find the strength to confront all this and save something from the ruins? And again and again, he returned to the Inner Light, with prayer for ald and faith

59 Ib1d., p. 205 
that was all but shaken to its roots. In h1s darkest misery there came to him this Iine from the Gospel of Mark: 'Lord, I belleve. Help thou mine unbelief,' spoken by the father who came to ask Jesus to heal his son." 60

At the same time, Stewart, in jail, was so overcome by thought of the trouble into which he had become involved that he concluded "he could never escape the jury of his own mind, of his father's mind: the judgment of the Inner Light." 61 He committed suicide. This blow on top of the others shook Solon to his depths. "His boy, his favority son--and dead by his own hand. And the sorrow! The shamel Almost, like Jesus on the cross, he was ready to cry, 'My God, my God, why hast thou forsaken me?'" 62

These trip-hammer blows were too much for Solon's wife and she died not long after Stewart's sulcide. Solon had quit his work after Stewart's death, and with the death of his wife he lost his mind. His daughters did all they could for him, trying to interest him again in the beauty of the country around their home which he had loved so much. He seomed to have reached some sort of inner peace which they

$$
\begin{aligned}
& 60 \text { Ibid., p. } 292 . \\
& 61 \text { Ibid., p. } 294 . \\
& 62 \text { Ibid., p. } 292 .
\end{aligned}
$$


could not touch. He began to observe the world of nature about him and regained his falth. His daughter read to him from Woolman's Journal. "The words she read, Etta noticed, seemed to affect her father as might some familiar and beloved melody. But to her they brought a dawning revelation of the meaning of faith. Here was no narrow morality, no religion limited by society or creed, but rather in the words of Woolman, 'a principle placed in the human mind, which in different places and ages hath had different names; it is however, pure and proceeds from God. It is deep and inward, confined to no forms of religion nor excluded from any, when the heart stands in perfect sincerity. In whomsoever this takes root and grows, they become brethren:" 63

Solon soon developed cancer and died, but he died peacefully and with his faith unshattered by all that he had been through.

This book, published some twenty years after his last novel is certainly an about face in Dreiser!s attitude toward religion. Solon definitely got solace from his religion. The Quaker faith is never ridiculed nor its practitioners commented on unfavorably. The religion is tied in with love and the book ends on this note for the sensitive character, Etta:

$$
63 \text { Ib1d., p. } 328 .
$$


In this love and unity with all nature, as she now sensed, there was nothing fitful or changing or disappointing--nothing that glowed one minute and was gone the next. This love was rather as constant as nature itself, everywhere the same, in sunshine or in darkness, the filtered splendor of the dawn, the seeded beauty of the night. It was an intimate relation to the very heart of being." 64

In The "Genius" Dreiser is contemptuous of religion as a solace for the individual. In An American Tragedy ho satirizes organized religion and leaves the solace to the Individual a moot point ot As for religion in The Bulwark, Dreiser is very sympathetic to its individual value and not unfriendly to the Quaker organization. He is still contemptuous of the ordinary insensitive man as we shell see later, but this does not detract from the theme which is definitely kind toward religlous feeling. However, desplte this friendIy attitude, religion did not bring a truly happy life. Even though Barnes retained his faith, he died a broken man. He was forced to withdraw from the world, his name shamed, his wife dead of a broken heart.

In summarizing Chapter III, I have shown that Dreiser treats religion first as the fulfillment of an individual need in time of stress. In The "Genius" he is contemptuous of the solace which religion offered Witla. Clyde in An

64 Ibid., p. 331 
American Tragedy seeks frantically for peace of mind through religion, but the reader is left with the feeling that he did not get it. On the other hand, in The Bulwark, Solon Barnes undoubtedly is comforted by his religion. This about face on Dreiser's part may mean that he mellowed toward religion in old age, or since he has never made any statements to the contrary, he may always have had a soft spot in his heart for the Quakers, whom he pictures as a tolerant, kindIy group of people. However, it is clearly evident that none of these diverse characters--one who did not want religion, one who sought religlous solace but failed to get it, and one who reached a high degree of religious feeling--altered the course of his life by any degree of religlous feeling he possessed. I have also shown how Dreiser treats organized religion as the embodiment of community morals, how he shows contempt for this aspect of religion and makes its advocates either ridiculous or hypocritical.

The following chapter will treat with Dreiser's attitude toward sex and its relation to his characters. 


\section{ATTITUDE TOWARD SEX}


CHAPTER IV

ATTITUDE TOWARD SEX

I shall show in this chapter that Dreiser considers the sexual drive as the basic human motivation. To him, it is a force over which man has no control. He believes that man's attempts to satisfy this unreasoning impulse are the bases for most human motivation, that in this urge for satisfaction lies the essential tragedy of life. Back of all his characters' actions is a sexual drive, and in each case an attempt to satisfy this impulse leads to a tragic ending. As I have stated above Dreiser belleves that sex is the basic human motivation. The following statements from Hey-rub-a-dub-dub, in which he sets forth his philosophy of Iffe, are proof of his opinion on this subject:

While it is true that some of the minor professors of psychoanalysis are offering what they are pleased to term the "sublimation of the holophilic (of sex) impulsen into more "useful", of, at any rate, more agreeable fields of effort via suppression or restraint, this in my judgment is little more than a sop, and an obvious one, to the moralists. What is actually true is that via sex gratif1cation--or perhaps better, its ardent and often defeated pursuit--comes most of all that is most distinguished in art, letters and our social economy and progress generally. It may be and usually is "displaced", "referred", "transferred", "substituted by", "identified with" desires for wealth, preferment, distinction and what not, but undermeath each and every one of such successes must primarily be written a deep and abiding craving for women, or some one woman, in whom the sex desires of any one person for the time being is centered. "Love" or "Iust" 
(and the one is but an intellectual sublimation of the other) moves the seeker in every field of effort. It is the desire to enthrone and enhance, by every possible detail of ornamentation, comfort and color--live, sensual gratification--that man in the main moves, and by that alone. Protean as this impulse may be, and it takes many forms, it stands revealed as the underlying reality of a thousand astounding impulses or disguises-pathetic, lying, simulating, denying, but the same old impulse everywhere and under all circumstances. Refracted as it is by opposition, misunderstanding, fallure into a million glistening and lovely or pathetic things, it may seem to be what is is not; but hold fast, trace it back, and there at bottom, sex appears, a craving for love, and its accompanying sensual gratification, and there is no other.I

Again in Dawn, in speaking of how he felt in his youth, of how he experienced the true joy of living, Dreiser emphasizos sex as the basis of life:

And by love I do not mean that poetic abstraction celebrated by the religionists--devold of sex--not yet the guttural sensuality understood of the materialist. My dreams were a blend of each: the diaphanous radiance of the morning, plus a suggestion of the dark, harsh sensuality of the lecher and the libertine--a suggestion merely, none the less a potent one which gave to all beauty and all reality a meaning. This, this, this contact joy between two was 1ts meaning! And this was its reward This and no otherl Architecture, trade, commerce, law, the political and social mules and activities of life: servants, servants merely, the under-pinning and surface-decorating of the great world altar on which the creative love or sex impulse made its bedi2

This sexual urge is, however, blind, and the seeking of its fulfillment is at the back of human frustration which I shall show in Dreiser's treatment of his novels under study here.

1 Hey-rub-a-dub-dub, pp. 134-135.

2 Dreiser, Theodore, Dawn, p. 210. 


\section{The "Genius"}

In accord with his theory that sex is the prime motivating influence among man's blind urges is Dreiser's handling of the sex drive in Eugene Witla. Witla is an artist, and the sublimation of his drive is never very far below the surface; this Dreiser also believes true in men with other talents and lesser drives as will be pointed out later in this chapter. Witla is closely entangled with many women; he has none of that faculty for sexual gratification within a monagamous relationship which allows him thereafter the free expression of his other drives in other outlets, for example, his art. He is particularly obsessed with the pursuit and conquest of beauty as symbolized by young, attractive women; because of this, his marriage was a mistake and a complete fallure.

Witla's whole pattern of life is foreshadowed in his first relations with a girl--a dull little girl who worked in a laundry with him. "Before this he had never physically known a girl. Now of a sudden he was plunged into something whlch awakened a new, and if not evil, at least disrupting and disorganizing propensity of his character. He loved women, the beauty of the curve of their bodies. He loved beauty of feature and after a while was to love beauty of mind,-he did 
now, in a vague, unformed way . - But, growing by what It fed on, his sex appetite became powerful. In a few weeks 1t almost mastered him. It burned fiercely for three months " 3 Then Witla began seoing the defects in this girl and quarreled with her and left her, as he was to leave so many more lialsons all through his life, with little regret.

About this time he met the woman who was eventually to become his wife. She was an attractive woman, a few years older than he, a fact of which he was unaware for many years. Her family were conventional, middle-class, small-town, middle western farmers. She would have been shocked by any extra-marital relations, and the very fact that he could not possess her was in itself a challenge to Witla. He courted her for several years, during which time he had several short romences with different types of women. At this time "he worshipped beauty as beauty, and he never missed finding a certain quality of mind and heart for which he longed. He sought in women, besides beauty, good nature and sympathy; he shunned criticlsm and coldness, and was never apt to select for a sweetheart anyone who could outshine him either in emotion or rapidity and distinction of ideas." 4

3 Dreiser, Theodore, The "Genius", p. 44. 4 Ibid., p. 75. 
At the same time he was ardently courting Angela, whom he had determined to marry, he was having an intense affair with a model from the art school he attended. Although he had some affection for the girl, yet he did not consider her feelings when he decided to break off with her, and left Chicago for New York without even telling her goodbye. In New York he met three women who had strong influences over him--two of them intellectually and the other both intellectually and emotionally. Here, for the first time, he came in contact with women who were his intellectual equals. One of them--a wealthy woman, many years his senior, who understood his creative Impulses and his art--was much taken with him, but since he could not outshine her, their meeting resulted in only a platonic friendship. A second platonic friendship developed from his acquaintance with a woman who held an excellent position as editor of a large magazine. The third and most interesting woman, from Witla's viewpoint, was an opera singer, who was much younger and more attractive than the first two, and who, if it had not interfered with her career, could probably have married him, since he recognized her intellectual superiority to Angela. Her problem was the satisfaction of her sexual urges without burdening too seriously her future as a singer; so she approached the problem on a rational basis, decided to have an affair with Witla, and then sever their relationship 
when she chose to do so. Since she was a resolute person and Witla did not insist on the continuance of their relations, the situation worked itself out as she had planned.

After these women, Angela paled for Witla; st1li she was the only woman he had wanted who had not succumbed to him, and this finally brought him back to her. When he revisited her this time, she allowed him to sleep with her, an act which, when it was once committed, brought feelings of remorse because of her moral convictions. She continualiy pressed him to marry her, and he gave her his promise to do so immediatelya promise which he fulfilled a few weeks later, making Angela very happy, but filling himself with many misgivings.

Not long after this marriage, he made his first exhibit as an artist--an exhibit which created an excellent impression for a new-comer and caused him to feel that he was going to be a successful artist. Angela, however, who saw that she was not holding Eugene as she thought she should, entered a period of sexual over-indulgence--

Beginning with their life in the studio on Washington Square, and continuing with even greater fervor now in Paris, there was what might be described as a prolonged riot of indulgence between them, bearing no relation to any necessity in their natures, and certainly none to the demands which Eugene's intellectual and artistic tasks laid upon him . . . Angela was in a sense elemental, but Eugene was not: ho was the artist in this as other things, rousing himself to a pitch of appreciation 
which no strength so undermined by intellectual subtleties could sustain. The excitement of adventure of intrigue in a sense, of discovering the secrets of feminine personality--these were what constituted the charm, if not the compelling urge of his romances. To conquer was beautiful: but it was in 1ts essence an intellectual enterprise... St1ll, he rejolced in this magnificent creature-joy which Angela supplied; it was, so far as it was concerned, what he thought he wanted ... He did not realize that he was, aside from his art, living a life which might rob talent of its finest flavor, discolor the aspect of the world for himself, take scope from imagination and hamper effort with nervous irritation, and make accomplishment impossible. He had no knowledge of the effect of one's sexual Iife upon one's work, nor what such a life when badly arranged can do to a perfect art--how it can distort the sense of color, weaken that balanced judgment of character so essential to a normal interpretation of life, make all striving hopeless, take from art its most joyous conception, make iffe itself seem unimportant and death a relief." 5

So Angela in her innocence took from Witla his talent. He was unable to paint. He lost out on all that he had built up for himself, and in addition to this, suffered a nervous breakdown. They spent years living around the country in poverty, sometimes with his family and sometimes with hers. This period ended when he left her with her family and secured a fob as a laborer in New York. Away from Angela, he began to recuperate and his desire to paint returned. Then followed an affair with another woman who was attracted to him--a married woman who was living with her mother at the time. Angela insisted on coming back East and

5 Ib1d., pp. 245,246. 
this complicated his affair and irritated him by curtailing the freedom which he had been enjoying. He, however, continued to carry on this illicit relation until Angela found out about it and forced him to break it off. Bitterness resulted. Although his fascination for the other woman had run its course, he resented Angela's interference in his personal Iife. "He suffered with her keenly, but not enough to offset his own keen desire for what he considered his spiritual right to enjoy beauty." Although he continued to live with her out of a sense of responsibility, yet she now knew she could no longer force him or hold him by her sexual powers. From a material point of view Witla now came to know the most successful phase of his life. He became assoclated with the advertising business as an artist and achieved tremendous success, finaliy becoming publisher of a great chain of magazines. Still he was only a salaried man, not the owner of the publishing house. The owner was very wealthy and admired Eugene for his talent but would and could break him at a moment's notice. In arriving at this successful point, he and Angela has gotten on very well because his business interests had not permitted time for feminine contacts; but after he had his job well in hand, he became quite a social

6 Ibid., p. 386. 
1ion. While his job did not exactly pall for him, still tho nature of his work made no demands on his artistic ability, and as a result his interests turned from the business to other things. He met and fell in love with a girl twenty years younger than he and she, in turn, was fascinated with him. They were faced with the problem of what to do about it since he did not at this time feel that he should undertake a stealthy liaison. The girl's family naturally objected to any extra-marital relationship, and he was torn between giving up his splendid position and the 11 fe of ease which he had made for himself or giving up the girl. He was willing to give up everything he had if it were necessary to have her, but he preferred to have her and still keep his good position. Witla was no true hero sweeping all before him. When he finally got to the girl again, after her mother had spirited her away and had placed all kinds of difficulties in his way, instead of gathering her up and running away with her, he was inclined to listen to the promises of her mother that she would aid in his divorce if he would agree to wait and not to ruin the girl's reputation. In the end he walted and lost everything--girl, position, and wife. The entire Iife of Eugene Witla is presented as a series of sexual relationships. All else is subordinate to this. Ho was an artist and his sexual drive was probably more pronounced than that of other men. From his initial affair with the 
laundry girl until he finally ruined his 1 ife and that of his wife to gratify a sexual urge, his Iffe is a shifting picture of more or less serious relationships with women. Everything else in l1fe was extraneous. "The more Eugene had looked at If $\mathrm{fe}$ through the medium of his experiences the more it had dawned on him that somehow all effort was pointless. To where and what did one attain when one attained success? Was it for houses and lands and fine furnishings and friends that one was really striving? Was there any such thing as real friendship in life, and what were its fruits--intense satisfaction? - . Only by the measure of his personal power and strength could he measure his friends--no more."7 Witla had also a rather strong creative urge plus a certain will to power, but both went down before his sexual impulses. The life, of Witla is an excelient demonstration of Dreiser's theory of the blind impulse running head-on into social convention, thus ruining the life and happiness of man. The same is true of Angela. Her love for Witla is blind and long-suffering. She allowed him to wreck her life, long after she saw that her love was not reciprocated but actually cast asida. She swallowed her pride and stayed with him to the bitter end, even giving up her life to hold him

$$
7 \text { Ibid., p. } 535
$$


when she must have known that nothing she could do would influence hIm to change.

\section{An American Tragedy}

In An American Tragedy, the sexual drive of Clyde Griffiths is manifested strongly in two ways: first, directly as a physical sexual satisfaction and second, as the basis for his need for social betterment. When clyde is only sixteen we see that ". . by that time the sex lure of appeal had begun to manifest 1 tself and he was already intensely interested and troubled by the beauty of the opposite sex, its attractions for him and his attractions for it. And naturally and coincidentally, the matter of his clothes and physical appearance had begun to trouble him not a little-how he looked and how other boys looked. It was painful to him now to think that his clothes were not right; that he was not as handsome as he might be, not as interesting. What a wretched thing it was to be born poor and not to have anyone to do anything for you and not to be able to do so very much for yourself." 8

The real story of clyde Griffiths is in his involvement with three girls and the subsequent frustration which his re-

8 An American Tragedy, Vol. 1, p. 15. 
lationships caused. The first girl was a cheap, flashy little gold-digger he met through his friends who worked with him as hotel bell-hops. She bled him shamelessly for all kinds of small presents and then spurned any efforts on his part toward sexual gratification. "But so keen was her attraction for him that he could not long remain away, but must be going about to where most likely he would encounter her."9 A little later in her greed to get a fur coat she promised to yield to him if he bought it for her, and such was his infatuation that he agreed to do this even though he knew that his family could not function without his financial aid. He allowed his family to worry out of their difficulty as best they could while he strained every resource for this girl, whom he felt that he must have, no matter what the cost. As usual with Dreiser's characters, after making this sacrifice, he did not get what he was looking for. Instead, he became involved in a hit and run accident during a return from a party with the girl, after which she ran off without giving clyde that which he had purchased from her.

This is a typical Dreiserian setup, in which the various characters follow courses into which they are driven by blind forces, against their so-called better judgment, into

$$
9 \text { Ibid., p. } 15 .
$$


some unhappy ending. They never learn from past experiences, since volition plays such a small part in their motivation, and they invariably come back for more punishment, usually in analogous situations.

Clyde's second important sexual adventure was with a factory girl who worked for him in his uncle's mill. By the time he met this girl things had changed for him considerably. He was still poor, but his rich uncle had taken him on in his business and seemed to be interested in seeing him get ahead. This placed clyde in a kind of social nomansland where, because of his connection with a werlthy family, he could not associate with the poor people, and, because of his own poverty, he could not associate with the rich people. In the factory there was a male which prohibited the worker from having any social relations with even the petty officials such as ho. Nevertheless, in spite of this, clyde and the girl, Roberta, were attracted to each other. "Day after day and because so much alone, and furthermore because of so strong a chemlc or temperamental pull that was so definftely asserting itself, he could no longer keep his eyes off her--or she hers from him."10

10 Ibid., p. 261. 
One day they met, accidentally, outside the factory, and in the course of a few weeks were meeting each other frequently. Clyde had learned one lesson from his past. When this girl refused to sleep with him, he angrily left her. "To have understood it correctly, the full measure and obstinacy and sulien contentiousness that had suddenly generated, one would have had to return to Kansas city and the period in which he had so futilely danced attendance on Hortense Briggs. For, although the present conditions and situation were different, and he had no moral authority wherewith to charge Roberta with any such unfair treatment as Hortense had meted out to him, still there was this other fact that girls--all of them--were obviously stubbom and self-preservative, always setting themselves apart from and even above the average man and so wishing to compel him to do a lot of things for them without their wishing to do anything in return." 11

So clyde put the lesson he had learned to use and was able to force the girl to give in to his will. The lesson proved of little value, however, since it led to an even worse downfall than the previous one. In the midst of his affair with Roberta, he met and became very much taken up

$$
11 \text { Ibid., p. } 303
$$


with a rich soclety girl. "Ah, to know this perfect girl more Intimately! To be looked upon by her with favor, -made by reason of that favor, a part of the fine world to which she belonged." 12 This girl to whom Clyde now aspired had actualiy taken up with him, not for himself, but to make his cousin angry. Clyde, not aware that he was a kind of social football, began to forsake Roberta Immediately. Much to Roberta's distress, he became more and more entangled in the upper soclal wh1rl, and her distress became panlc when she discovered that she was pregnant. She reminded clyde that he had promised to take care of her if that situation arose, and he might have married her had he not been so infatuated with Sondra and her wealth. All he could think of was some way to get rid of Roberta. When Sondra returned Clyde's Infatuation and told him that she would find some way to marry him in spite of the opposition of her family, she sealed Roberta's fate. The time had come when he was forced to act; he must either marry Roberta or she was golng to expose him. And here Dreiser gives the reader a glimpse into Clyde's thoughts as he plans a way out:

12 Ibid., p. 317. 
But she will not let you go or go ber way unless you accompany her. And if you go yours, it will be without Sondra and all that she represents, as well as this pleasant life here--your standing with your uncle, his friends, their cars, the dances, visits to the lodges on the lakes. And what then? A small jobl Small pay! Another such period of wandering as followed that accldent in Kansas City. Never another chance like this anywhere. Do you prefer that? . . But a little blow--any little blow under such circumstances would be sufficient to confuse and complete her undoing. Sad, yes, but she has had an opportunity to go her own way, has she not? And she will not, nor let you go yours. Well, then, is this so terribly unfair? And do not forget that afterwards there is Sondra, the beautiful, a home with her in Iycurgus, wealth, a high position such as elsewhere you may never obtain again-never-never. Love and happiness--the equal of anyone here-superior even to your cousin Gilbert."13

So with this vision of sexual gratification and advanced social standing, Clyde determined to murder the girl who stood in his way. She was in his way because he had used her to satisfy an earlier sexual drive which he had been unable to control. Dreiser is very clear on the point that Clyde is not a villain, but only a victim of forces beyond his control. "He had been swayed by his obsession for Miss $X$, the supermotivating force in connection with all of this." 14 Then, too, the lawyer's description of clyde to his partner-"This fellow is by no means as hard as you think, or as cold-quite a simple, affectionate chap, in a way, as you'll see for

13 An American Tragedy, Vol. 11, pp. 50-51.

14 Ib1d., p. 388 . 
yourself--his manner, I mean."15_-bears out the fact that clyde was not guided by a malevolent destiny as though he were a chess man, but that he was a being moving as blindly as a bug or a dog with no rational control over his actions. This situation fits perfectly into Dreiser's philosophy of the world as an uncontrolied and uncontrollable series of actions which has nothing in common with the wants and fears of any man. A man is tossed into the scene and blindIy plays his part. It matters not at all that he is a simple, affectionate fellow; when he follows his impulses, he is going to be acclaimed a scoundrel and a viliain.

Dreiser presents Clyde's prosecutor and defender as symbols for avenglng soclety and tolerating society. The prosecutor was the son of a poor family who, at the age of - "fourteen, while skating had fallen and broken his nose in such a way as to forever disfigure his face. Thereafter, feeling himself handicapped in the youthful sorting contests which gave to other boys the female companions he most craved, he had grown exceedingly sensitive to this fact of his facial handicap. And this had eventually resulted in what the Freudians are accustomed to describe as a psychic sex scar."15

$$
\begin{aligned}
& 15 \text { Ib1d., p. } 191 . \\
& 16 \text { Ib1d., p. } 92 .
\end{aligned}
$$


This man could see clyde only in the blackest light possible, while, on the other hand, Clyde's defender.. "was one who would naturally approach a case such as clyde's with less vehemence and fever than did Mason. For, once, in his twentieth year, he himself had been trapped between two girls, with one of whom he was merely playing while being seriously in love with the other. And having seduced the first and being confronted with an engagement or flight, he had chosen flight."I7 Here Dreiser lines up the forces of society in these two men as they fight over the helpless victim. Although both are agreed that sex was the cause of the tragedy, jet one claims that it is a heinous crime and the other an unfortunate accident. Dreiser sides with the boy against society; but he realizes that the dice are loaded against $\mathrm{h} 1 \mathrm{~m}$, and clyde is convicted and dies for a crime for which he is no more responsible than the prosecutor for his broken nose. This, then, is the story of clyde Griffiths who was caught between the hammer of his uncontrollable sexual desires and the anvil of social conformity which prescribes only certain clrcumscribed outlets for those desires. He was crushed by a fate which had no understanding of, or interest in his problem. As Dreiser sees 1t, this is the inevitable fate of

17 Ibld., p. 183. 
man. Driven by fórces beyond his control to seek that which he cannot have without destroying himself, he has no choice but to seek and be destroyed.

\section{The Bulwark}

Solon Barnes, in The Bulwark, is quite different from the other characters in this study in that his sexual drive was easily satisfled through the family relationship approved by soclety. For him, sex was something to be frowned on and suppressed as far as possible: ". - there had come to him, between his tenth and eleventh years, along with the entire citizenry of Seegookit, an experience which was destined to Iive permanently in his mind and which, while clarifying the Import of sex as a force, served to darken his view of it as something which unless properly directed was preferably to be avolded entirely."18 This event was the closing of a house of 111-repute which had been set up for the factory workers of the town, and the move was made by a group of religlous people which included his father. Thus, at an early age, Solon had come to realize that sex was disruptive social force which must be repressed for the good of society.

18 Dreiser, Theodore, The Bulwark, New York; Doubleday and Company, 1945, p. 33 . 
It cannot be sald that Solon was immune to the attractions of sex; he was early drawn to Benecla, whom he later married, and "The chemically radiated charm of her, temperamentally and physically was sufficlent to keop him in a strained and nervous state, like one who suffers from a high fever." 19 However, when he had won her consent to marry him, he did not burn to possess her immediately as Witla or Clyde Griffiths would, but was content to walt unt1l her father thought him able to support her in a proper manner before the marriage was consummated. The story of the sexual drive in The Bulwark is the contrast between Solon and his children. He lived an even life fllled with spiritual peace and calm, while his children were torn by the more common desires of ordinary people. His oldest son was a dull uninteresting clod whose only desire was to be a respected and respectable citizen without doing anything to earn such a position. For example, "Orville's thoughts began to dwell longingly on the prestige attaching to marriage into the wealthy Stoddard family. Al tha was not a Friend at heart; to her as to orville, the precepts of religion were more socially than religlously significant. But with such a marriage he would be rich, secure, comfortable,

$$
19 \text { Ibid., p. } 37 .
$$


respected and admired, and he wanted no more than that in this world."20

Solon's daughters were quite different. The eldest was an unattractive girl who pined for sexual companionship-a companionship which she never achieved except for a platonic friendship with a college professor to whom she later became assistant. The second daughter, a pretty girl, rebelled slightly against her father's stern religious precepts, and, with the aid of an aunt who was not of such a religious bent, met a socially accepted young man and was also respectably married. The actual rebellion came from the youngest daughter and son. Etta's "temperament was reserved and yet yearming, but unlike her mother's, who had yearned, but always with repression and unquestioning meekness. She knew her parents loved her, but somehow they could not understand or respond to her inner needs."2l As a consequence, she ran away from home to escape the repressions of her family, wound up in Greenwich Village as an artist's model, and finalIy became mistress of the artist who understood her so much better than her family.

In contrast to Dreiser's portrajal of restlessness in

$$
\begin{aligned}
& 20 \text { Ibid., pp. 148,149. } \\
& 21 \text { Ibid., p. } 160 .
\end{aligned}
$$


the Barnes' children, is his description of the Barnes' parents after twenty-five jears of married life:

Benecia, in her simple gray dress, with a white kerchlef round her neck, studied her earthly mate with the same living interest that she had bestowed upon him twenty-five jears before, when she had promised to take him for her wedded husband. When they were alone together, they were not lonely. He was so kind to her, so considerate at all times, so honest, so careful of his word, so thoughtful of all that he was called upon to do, avoiding all that did not legitimately or charitably concern him. Yet to-night as they sat opposite each other, the cleanly, buxom Christina, in blue-striped gingham and crisp, white apron, attending to their needs, the atmosphere a round them seemed too fixed, too still. It was all too well-ordered, too perfect for frail, restless, hungry, human need." 22

This Iife which Solon had been able to build for himself and in which he reared his children was ideal, but it was so perfect that he was not able to make his children fit into 1t. His oldest son conformed to the pattern because he was dul1, the oldest daughter, because she lacked the fire of the younger children. The second daughter rebelled but was fortunate enough to find her outlet in a socially accepted pattern, although 1t was outside her father's stern rules. Then the younger chilaren broke out in open rebellion because they had more drive and perhaps, because they were influenced by the partial breaking-away of the older children which caused them to go even further.

22 Ib1d., pp. 184,185. 
Stewart, the younger son, reacted exactly opposite to his father, who had been brought up in the same kind of home which he had set up for his children, and in which he had accepted the precepts of his parents without question. Stewart, on the other hand, could not see his father's way at all, as

is shown in the following quotation:

Stewart bowed his head humbly. He felt there was something in what his father was saying, and yet it irritated him. Why should he clte orvilie? And why should he insist that he would have to make his own way when he had plenty of money? And why was he never allowed to have a good time? He was sick and tired of hearing about the Inner Iight. Its impact as far as he was concerned, was purely imaginary. And as for George Fox, and John Woolman's Journal, quoted to him so often, he wasn't interested in them. They had nothing to do with real iife. 'Real Iife,' to Stewart's way of thinking, was depicted in all 1ts glorious details in the pages of certain publications which his father would have considered detestable had he even surmised their existence. Stewart devoured them with eager eyes down at Rodenheaver's bookstore: the Standard and the Police Gazette, with their pictures of showy, half-dressed chorus giris, and the 'Johnnles', or 'glided youths' or 'young bloods' or 'men about town' as they were variously titled and referred to, whose sole business in Ife it was to entertain such maldens. He even dreamed of them, these night flowers of the big city.23

Stewart was obsessed with thoughts and desires such as his

father had never known. Something of this same sex longing had been evident in his eldest sister, Isobel, but in Stewart it was "many times strengthened and without the conservatism

$$
23 \text { Ib1d., p. } 195 .
$$


of soul that regulated and controlled Isobel... In fact he was cursed with an overwhelming hunger for physical sex gratification." 24

Solon, understanding none of this, did all in his power to curb the boy, but, if anything, succeeded only in making matters worse. Stewart began to go out with his schoof mates to clandestine meetings with girls of easy virtue. Finally, on one of these expeditions, a friend of his gave a girl, who was withholding her charms, a drug which caused her to yleld to both himself and stewart. Because she had a weak heart, the drug killed her, and the boys were involved in a murder and rape charge. Enough of the Quaker teachings of the boy's youth so overwhelmed him that he comitted suicide because of the disgrace he had brought on himself and his family. Here Dreiser again emphasizes the inability of man to control his desting. The blind forces of life break through any bounds which he mey try to set up for himself or his family. Solon was able, however, to solace himself with his religion. At his death, his other errant child, Etta, was the only one who was able to understand her father and the forces with which he struggled. Dreiser says of her:

24 Ibid., p. 244 
". Etta, of all the others, and despite the constant and loving services she had rendered her father since her return from New York and her defeated love, continued to feel her compulsive share in this tragedy. Her fatherl Her motherl Her own erratic, impulsive career! Now she realized the strain under which they had Iived, ever since the time she had deserted their homel Her love-seeking youth! Her complete lack or understanding of her father's spiritual ideals fore the driving thirst of stewart for material show and sensual pleasure had ended in his self-extinction--death by his own hand She remembered her own sensual, selfish dreams--what had all this meant and what did 1t mean now?" 25

When she cried at this time, her brother, Orville, whose only feeling in the matter was one of shame because of the notorlety of his brother's death and his injured social standing, rebuked her, saying that she had caused her father's death. To this, Etta replied, "Oh, I am not crying for myself, or for father-I am crying for $11 \mathrm{fe} . " 26$

She is the understanding character for Dreiser, one who is weeping for the tragedy which must be--the inevitable frustration of man's plans and desires. Solon Barnes had a much better chance for a happy ife than either Witla or Griffiths because his temperament did not cause him to run counter to society; but, when he tried to force the same rigorous patterm on his children, he falled and brought about

$$
\begin{aligned}
& 25 \text { Ib1d.. p. } 336 . \\
& 26 \text { Ibid., p. } 337 .
\end{aligned}
$$


his own destruction. The life forces which had been so kind to him by remalning quiescent came back in full force in his children, and he was unable to control these forces any more than if they had been inherent with him. His very attempt to conform by living a 'normal' life and rearing a family in the accustomed way brought about his down-fall. Without a family, he would doubtless have been unhappy because he had been brought up to believe that a family was one of the prerequisites for happiness, yet it scarcely seems possible that he could have been as unhappy as he was in the traglc circumstances into which his family forced him.

To sum up all of the evidence presented in this chapter, I find that: To Dreiser, sex is the motivating force behind individual action, and he shows how this drive will sooner or later cause the individual to conflict with society and bring about his undoing. 
ATTITUDE TOWARD ECONOMIC STATUS 


\section{CHAPTER V}

\section{ATTITUDE TOWARD ECONOMIC STATUS}

In Dreiser's opinion, economic and social status have little influence in the molding of men's lives. In spite of the fact that they are of utmost importance in the eyes of men, economic and social power are as nothing compared to the larger forces which control their lives.

Dreiser has, I think, an American attitude toward social status. H1s characters have that Horatio Algerish characteristic of believing implicitly that they will get ahead in the world; they are not conscious of class as a IImitation on themselves. Not one of his principal characters is a person born with a silver spoon in his mouth, neither is he a worker's child. His characters come from backgrounds which are always petit bourgeols, and with the exception of Clyde Griffiths, they all attain some measure of economic success at some time in their lives.

\section{The "Gen1us"}

In The "Genius", Dreiser begins with this description of Eugene Witla's family: 
In one part of this city there lived a family which in its character and composition might well have been considered typically American and middle western. It was not by any means poor-or, at least, did not consider itself so; it was in no sense rich. Thomas Jefferson Witla, the father, was a sewing machine agent with the general agency in that county of one of the best known and best selling machines made. From each twenty, thirty-five, or sixty dollar machine sold, he took a profit of thirty-five per cent. The sale of machines was not great, but it was enough to yield him nearly two thousand dollars a year; and on that he had managed to buy a house and lot, to furnish it comfortably, to send his children to school, and to maintain a local store on the public square where the latest styles of machines were displayed... . He also repalred machines, -and with that peculiar energy of the American mind, he tried to do a little insurance business on the side.1

Out of this environment Eugene Witla, destined to become a great artist and, for a time, a power in the publishing world, was born. What could be more typically Amer1can? There is nothing exotic here, no contrast of coming out of the depths of some economic or psychological conflicts as the European or proletarian writers would have us believe. Anything is possible to an American; he can emerge from such a background and still aspire to be a business tycoon, a president, or a great artist--how he exploits his talents depends on himself. This is the American attitude, the American ideal; however, Dreiser differs from the 'slick' writers, who exploit this 1dea to a happy ending, with his conception of the es-

\section{The "Genius", pp. 9,10 .}


sentially tragic nature of the whole procedure. This man, Wtla, goes ahead, becomes a great artist, has, for a period, great financial success, but in the end he is frustrated. Man is set in a soclety, which, in America, is quite fluid. Theoretically, it appears that he has a large measure of control over his destiny, but, in reality he is only part of forces over which he has no control and does not in the least understand. These forces take no cognizance of the values man has set up for himself and push him into circumstances where he has to repudiate those things which he had thought he valued most highly.

Witla, at first, aspired to be a great artist and after several years of study and work achieved a rather high degree of success only to be battered down and all but forgotten because of a nervous breakdown brought on by sexual excesses. After a period, he made a meteoric comeback as a commercial artist, advertising expert, and at last achieved complete success as managing publisher of the greatest firm of 1ts kind in the nation. But to what effect all of this? He became a respected member of the elite social set of his day; to all outward appearances he had all that a man could wish--power, wealth, prestige; but it was a house of cards, blown down in a moment.

This success was reached through a series of fortui- 
tous circumstances which gave Witla the impression that his standing was much more solid than it actually was (not that the solidity is really important, as we shall see in The Bulwark). His talents were extremely useful to three men who were in the process of expanding their businesses at the time be came 1nto their notice; and when they bid against each other for his services, the final bid, which he accepted, was very high. As a result he received the impression that he was indispensable, and came to think of himself as a permanent member of the social realm in which he moved by virtue of the prestige of his new position. However, he had risen only so high in order that he might fall farther when his inevitable debacle came about.

When those uncontrollable forces within him pushed him into a relationship with a girl, which the society in which he moved would not countenance, his world fell apart. He lost his economic position, his social standing, and final1y, the girl for whom he had been willing to sacrifice all. Then his wife died, robbing him of whaterer family and emotional securlty he had in his home. His friends fell away faster than the leaves in autumn; no wonder he vented that bitter soliloquy quoted in the previous chapter.2

$$
2 \text { supra., pp. } 61,62 \text {. }
$$


Dreiser's treatment of Eugene Witla's Iife leaves no doubt but that he believes economic status has little effect on the ultimate outcome of I1fe. Economic position means nothing to those forces which control man's destiny; it gives him no security whatever in the battle for control of his $11 \mathrm{fe}$

\section{An American Tragedy}

In his characterization of Clyde Griffiths, Dreiser again shows the typically American attitude. Clyde had very Iittle formal education and no special training for any particular occupation. He quit school early to go to work. When he was looking in the papers, which being too worldly, had never been admitted to his home, he found that mostly skilled help was wanted, or boys to learn trades in which at the moment he was not very much interested. For, true to the standard of the American youth, or the general American attitude toward life, he felt himself above the type of labor which was purely manual. 3 It made no difference that he was uneducated; he felt that he was destined to get on in the world. He had no understanding of the importance of some training, some talent, or perhaps some luck which it takes to attain success.

3 An American Tragedy, Vol. 1, p. 14. 
Dreiser exemplifies that peculfarly American idea that every man will get ahead if he puts his shoulder to the wheel--the attitude which excludes the millions of examples of those who fall and looks to the exceptions of those who succeed. That Clyde was oblivious to his ineptness is well demonstrated by a little byplay which took place at a party of the young soclal set into which he had wormed his way by being the nephew of a wealthy manufacturer. He was at this time a sort of straw boss over a small department in his uncle's factory and was for the first time coming into social contact with that world of which he had been dreaming. All of the young men in that clique were graduates of eastern colleges. One of them to whom Clyde was introduced--a young man "of a commercial as well as technical turn"--remarked:

You know . . I've always wondered just what, outside of money, there is to the collar business. Gil and $I$ used to argue about that when we were down at college. He used to try to tell me that there was some social importance to making and distributing collars, giving polish and manners to people who otherwise wouldn't have them if it weren't for cheap collars. I think he must have read that in a book somewhere. I always laughed at him.

Dreiser shows Clyde's utter inability to cope with the situation in the following quotation:

Clyde was about to attempt an answer, although al ready beyond his depth in regard to this. 'Social importance.' Just what did he mean by that--some deep scientific information that he had acquired at college. He was saved a non-committal or totaliy uninformed answer by Sondra who 
without knowledge of his difficulty exclaimed: 'No arguments, Freddy. 14

Th1s did not perturb Clyde in the least. He neither made any effort later to find out what the young man was talking about nor gave up his idea that he was quite capable of coping with such people if given the chance by marriage into their circle. This blind belief that he could hold any position of power or trust is, I am sure, purely American, and Dreiser seems to have captured the attitude perfectly.

In neither of the three novels is there much discussion of the American economic system, but there is a long exposition of the workings of American justice in CIJde Griffiths' trial for murder. I have already referred to the psychological attitudes of the opposing lawyers in this trial In chapter three and will now discuss the political and legal espects of it.

As previously mentioned, Clyde became a political football because Roberta's death occurred in the late summer of an election year. The possibility of favorable publicity, connected with convicting clyde of murder, was so strong that the party in power, represented by the prosecuting attorney, called for a special court in order to have the trial before election time instead of holding it at the regular later ses-

$$
4 \text { Ib1d., p. } 330
$$


sion. One over-zealous member of the prosecutor's staff went so far as to falsify the evidence by taking some of the hairs from Roberta's head and placing them in Clyde's camera so that the prosecution would have proof that he struck her. In a set-up of this kind, it was only natural that Clyde's defenders would come from the opposition party. Justice was not the 1ssue, but political prestige. If clyde were convicted, the prosecutor's political future would be assured; he would be elected judge and would carry his entire ticket with him. If Clyde were freed, the opposition would sweep the incumbents out of office. This was the main issue with the lawyers, not the question of whether the boy were guilty or not. The whole countryside was stirred by the prosecutor's assertions concerning clyde's guilt. Opinion was swayed by the idea that ke, apparently a member of the socially elite group, had led an innocent young girl astray and that, whether he murdered her or not, he should be convicted. The pitiful letters which Roberta had written Clyde were the most damning evidence against him. These letters were copied from the prosecutor's files and circulated throughout the community with the result that, when the trial came, the members of the jury "were all convinced of clyde's guilt before they ever sat down." 5

\footnotetext{
5 An Americán Tragedy, Vol. 11, p. 231.
} 
Dreiser's treatment of this trial is an indictment of the American judicial system. The trial is a mockery of justice as professed under our system of government. It really mattered not whether he had committed the murder, he had violated social custom and must be made to pay for his transgression. In addition to the social opprobrium which he had to face, he was the victim of a political ambition, both of a party and a man. The prosecutor, instead of looking at the facts and presenting them to the court without bias, was determined to obtain a conviction, regardiess of the question of guilt, in order to further his own ambitions. Dreiser is not indicting the man, however, but the entire system which makes such a mockery possible. There is nothing to indicate that, had another party been in power and had another man been in the prosecutor's position, the results would have been different. According to Dreiser, it is the system and not the man which is at fault. To return to the question of whether or not economic status affects the inevitable frustration of man's life, apparently, it does not. Economically and socially speaking, it would be difficult to get two men further apart than Witla and Griffiths, jet both suffer defeat. clyde is a mere nothing on the economic scale, while outwardly witle is a power, yet their positions did not alter their downfall in any manner. Both are victims of forces beyond their control. Both violated the mores 
which dominated their soclety and both had to pay the penalty. Frustration was as tragic to one as it was to the other. Incidentally, it is interesting to note that there is one reference which tends to show that economic power is instmmental in smoothing over some difficulties. It is the incident where Clyde's lawyer gets into a scrape with a girl referred to in chapter four and is able to escape from it because his father could afford to pay the girl a sum of money after which the young man hid out away from home for a year until the scandal blew over. 6 Possibly if clyde had been the son of a wealthy father instead of the nephew of a wealthy uncle he could have bought Roberta off. To that extent, Clyde's economic status' trapped him. However, in the light of Stewart Barnes' experience, it cannot be said that economic security played any part in saving the victim.

\section{The Bulwark}

Dreiser places his character, Solon Barnes, in an entirely different economic set-up from that of either Eugene Witla or Clyde Griffiths. His entire life bespeaks solidity. Solon, however, is like the others in that he is a poor boy believing that he will "make good". He had no meteoric career,

6 Supra., p. 69. 
but experienced a steady rise to solid, respected position. His father was a busy man and he, in turn, began to learn the ways of business at an early age. That Rufus Bames realized the need of practical business training for his son is evident in these Iines:

Plainly he [Rufus] had many places to visit, and Solon soon began to learn something of them for himself, for his father, still anxious to further solon's practieal understanding of life, quite frequently invited him to go with him on Saturday as he made his last commercial round of the week. Also, in midweek, on occasion after school he would have Solon meet some of his new customers . . . . Besides, Rufus proceeded to explain to Solon the details of mortgage transactions.7

As a result of this experience with his father, Solon obtained a position in his future father-in-law's bank from which he worked himself up to a position of power and trust. He acquired a wholly justified reputation for honesty and integrity which made him highly respected in the financial circles in which he moved.

Here, for the first time in the books under discussion, Dreiser gives a picture of American business. After many years Solon became a high officer in the bank, and, "If he had been of a slightly different order of mind at this time, he could have advantaged himself greatly, for he was

7 The Bulwark, p. 28 . 
now well within the gates of a highway leading straight to a large, and even immense fortune. The men with whom he was now connected were exactly of the temperament which organizes, suborns, controls. They had no morals as to matters of f1nance, though in other respects they were normal and conventional, and all of them were inclined to like Solon." 8 These men were engaged in some very unsavory transactions between the bank and certain companies in which they were also interested. When they manipulated the bank's funds in such a manner that the bank was placed in a precartous situation, Solon, not wishing to injure either the bank or 1ts depositors, hit upon the idea of informing the treasury department. This he did in such a way that the bank officers were warned without publicity to straighten out their affalrs. This move forced them to set the bank aright without injury to the bank's depositors, but it did not endear solon to the officers.

Here is a character as economically solid and secure as a man can be. He is not subject to the whims of a boss; only the overthrow of the entire system in which he lives can injure his economic status. He has not only the appearance but also the substance of economic security, yet his iffe ends as tragically as that of the other men under discussion.

8 Ibid., p. 221. 
Plainly the forces which control men have no respect for human standards. I have al ready pointed out what a good man Solon was according to other social standards--he had all of the virtues which men admire and none of the vices which they condemn, yet he is frustrated in his search for a happy iffe. Actually, Solon's understanding that mere economic security based on the possession of ample funds is not enough to assure happiness in this world, was a strong factor in his own undoing. It came about because he sought to prove this thesis to his son by his own assertion of 1t. The boy could not understand what his father was trying to do for him. He saw only his father's ample means which were withheld from him, while his friends' parents furnished them with much more liberal allowances. This further estranged him from his father's precepts. A sort of vicious circle developed where the boy sought and received money from weal thy relatives who did not understand Solon's motives in withholding money from his son; then the boy went into more decelts necessitating more money and more deception until he finally became involved in a murder-rape charge and brought the ent1re family into disgrace.

We cannot draw from this 1llustration, however, that the possession of money is the root of evil, since just the opposite is the case with Clyde Griffiths. Clyde, in contrast 
to Stewart Barnes, was never profligate. Both boys possessed an overpowering sex drive. One had access to relatively ample funds and the other had to earn whatever he spent, yet both wound up in the same predicament. Neither was able to escape his drive which held him up for social contempt, and both were run down and destroyed by that social force which they encountered.

I would like to note here that Dreiser, who is continually concerned with the elemental and seemingly eternal drives and conflicts of man, never mentions war. He must have been conscious of war and its effects on society--of its power to accelerate social change and increase human passions, or at least their outward manifestations such as the marriage and divorce rate; yet in neither of the last two books I have discussed, which were written after the first World War, is war mentioned at all. An American Tragedy takes place before the war and can easily be ignored, but The Bulwark carries through the last war period without so much as a mention of it. It seems logical that it would have had some bearing on Solon with his Quaker training and perhaps caused some contention between him and the poople of his community. It is posible that Drelser feels that wars are only incidental disturbances and that they really do not affect the drives and conflicts which he considers much more important and basic in influencing 
man's actions; or it may be explained by the fact that Dreiser's age was such that he was never vitally affected by the war and thus ignores it on the basis of his own experience. To return to the topic under discussion in this chapter, I find that Dreiser considers economic security no safeguard against the larger forces of which man is a toy. In some minor, man-made difficulty, wealth may smooth the way for the offender; but when he comes in conflict with the larger, impersonal forces which dominate life, man's wealth avails him nothing. Both rich and poor are victims of an amoral force which they can no more control than they can control the movement of the earth around the sun. 
CONCLUSIONS 


\section{CHAPTER VI}

\section{CONCLUS IONS}

Dreiser sees man as an essentially tragic individual and portrays him as such in the three novels under study in this paper. He is the spokesman for the spirlt of his age. There were other realists of his time, but Dreiser was the first to break out forcefuliy and fearlessly with the plain unvarnished truth. He was the first to reflect the darker aspects of an otherwise prosperous, outwardly plac1d American landscape. His philosophy shows the effect of the impact of the new science on man's opinion of himself. No longer was man the important center of the universe or the apex of a vast evolutionary ediface; he was only one small part of a great heaving mass, which had no director and no direction. In view of this attitude of the nature which underlay man and his actions, man's aspirations and desires became puny, unmarked scars on the fact of nature. Dreiser's world ceased to be a great becoming for all men, but came to be, instead, a snare wherein all were trapped.

It mattered not whether a man were great or small according to the standards of man, according to nature, he was merely another speck of energy to be smashed if he stepped in the path of the jusgernaut in its thrashing about. Drelser 
uses specifically the sexual drive of the individual to bring him in conflict with the necessities of society, embodied in religion, which in turn brings about his frustration and the collapse of his aspirations. This sexual drive is some inherent part of man's nature, his chemical make-up; he cannot escape or control 1t, and in trying to sate 1t, he runs headlong into the needs of the group, or society, which has set up certain standards of conduct for its own preservation. Dreiser uses this method in all three of his books-The "Genius", An American Tragedy, and The Bulwark. Witla loses wealth, position, wife, sweetheart, even his ability to paint, in his pursuit of sexual gratification. He runs straight into social sanctions which beat him down into submission. Clye Griffiths loses position, sweethearts, and finaliy life. itself, in his drive to gratify this blind, powerful urge. He, too, heads into the wall of social opprobrium and is beaten down. Then Solon Barnes is led along the same paths by his son, who possesses the same drives and needs as Witla and Griffiths, and who also loses his position and his sweethearts, and eventually takes his own life. Solon, in the long run, is no better off than if he had done the same things himself; he, too, loses his wife, position, health, and happiness through these same urges in his boy. 
In these novels Dreiser points out that nature is no respecter of wealth. Witla's sexual drive was no more or less powerful whether his fortune was up or down. He needed women and their approbation both as a poor student and as a wealthy, successful business executive. Clyde Griffiths, to be sure, was never wealthy, but he had what appeared to be security by obeying his uncle's precepts on conduct; however, he completely dis regarded the rules in his desire for Roberta and the satisfaction of his chemic urges. The characterization of Stewart Barnes is perhaps the best evidence that wealth has no bearing on the workings of nature. Stewart had money, se-: cure position, and love from an excellent family, but all of this was no help to him when his natural urges came forth; he had to gratify these urges, and they brought about his downfall just as surely as they brought about the downfall of Clyde Griffiths.

Man is the victim of his desires. Dreiser does not Iike this, but he sets it down as he sees it. It is a tragic happening, and he is protesting against it as he writes about 1t. If Drelser had not taken the matter so seriously, he could have treated it with humor as some of his contemporaries chose to do; but to him the plight of those who fail is pathet1c--pathetic enough to cause him to spend endless hours of melancholy, troubled brooding over their fate. 
In Dreiser's opinion, all men are not equal. Some are more sensitive than others, and it is the sensitive ones who have the eplc struggles. They are the men who strive to change things, who seek and are broken in the search. The world is composed mostly of men who submit to the rules and who then seek submission in others. These are the people who keep the soclety together and against whom the sensitive men are broken in their striving.

The only mellowing detectable in Dreiser is at the end of his life when he permits Solon Barnes, a major character, to achieve religious solace in his great crisis. He had, however, previously allowed Griffiths' mother to achieve the same thing. I think, in doing this, that he is recognizing a well-known fact, namely, that religlous experience is quite real to some people; and he would be foolish to deny that to some of his characters if they are to be truly representative of the whole people which he is trying to portray.

I cannot see any change in his attitude, as a whole, throughout the thirty years spanned by these novels. The characters have the same motivations, the same traglc endings to their lives in all three of the novels. Dreiser ended as he began, with a belief that man is a product of natural forces which are impersonal and non-teleological--forces which 
w111 crush a sensitive man who is forced to act from the impulses of an inner nature over which he has no control. Dreiser's great contribution was his fearlessness in plodding ahead in the face of opposition of the nice people. His greatest critical detractor was Stuart P. Sherman, who condemned him for confining "himself to representation of an1mal behavior."I This was the gist of the criticism of his attackers, namely, that he ignored all that was good and beautiful in American life. These critics were moving in a dream world of high society where the stench of American Iife could not reach them. In answer to Sherman's criticism of Dreiser, Parrington wrote: "Shall these impulses be eliminated from literature or from life itself."

For a conclusion of this paper, I know of no more moving or more excellent evaluation of Dreiser than the tribute paid him by Sherwood Anderson in dedicating Horses and Men:

1 Sherman, Stuart P., on Contemporary Iiterature, New York, Henry Holt and Company, 1917, p. 94.

2 Parrington, Vernon Louls, Main Currents in American Thought, p. 359 . 


\section{DREISER}

Heavy, heavy, hangs over thy head, Fine, or superfine?

Theodore Dreiser is old--he is very, very old. I do not know how many years he has lived, perhaps forty, perhaps fifty, but he is very old. Something grey and bleak and hurtful, that has been in the world perhaps forever, is personified in him.

When Dreiser is gone men shall write books, many of them, and in the books they shall write there will be so many of the qualities Dreiser lacks. The new, the younger men shall have a sense of humor, and everyone knows Drelser has no sense of humor. More than that, American prose writers shall have grace, lightness of touch, a dream of beauty breaking through the husks of IIfo.

0 , those who follow him shall have many things that Dreiser does not have. That is a part of the wonder and beauty of Theodore Dreiser, the things that others shall have, because of him.

Long ago, when he was editor of the Delineator, Dreiser went one day, with a woman friend, to visit an orphan asylum. The woman once told me the story of that afternoon in the big, ugly grey building, with Dreiser, looking heavy and lumpy and old, sitting on a platform, folding and refolding his pocket-handkerchief and watching the children-all in their little uniforms, trooping in. The tears ran down his cheeks and he shook his head,' the woman said, and that is a real picture of Theodore Dreiser. He is old in spirit and he does not know what to do with life, so he tells about it as he sees it, simply and honestly. The tears run down his cheeks and he folds and refolds the pocket-handkerchlef and shakes his head.

Heavy, heavy, the feet of Theodore. How easy to pick some of his books to pieces, to laugh at him for so much of his heavy prose.

The feet of Theodore are making a path, the heavy brutal feet. They are tramping through the wilderness of lies, making a path. Presently the path will be a street, with great arches 
overhead and delicately carved spires piercing the sky. Along the street will run children, shouting, 'Look at me. See what $I$ and my fellows of the new day have done' -forgetting the heavy feet of Dreiser.

The fellows of the ink-pots, the prose

writers in America who follow Dreiser, will have much to do that he has never done. Their road is long but because of him, those who follow will never have to face the road through the wilderness of Puritan denial, the road that Dreiser faced alone.

Heavy, heavy, hangs over thy head, Fine, or superfine? ${ }^{3}$

3 Anderson, Sherwood, Horses and Men, New York, B. W. Huebsch, Inc., 1923, pp. xi, $x_{11}$. 
BIBLIOGRAPHY 


\section{BIBLIOGRAPHY}

\section{A. BOOKS}

Anderson, Sherwood, Horses and Men. New York: B. W. Neubsch, Inc., 1923. pp. $\overline{\mathrm{xI}} \times \mathbf{X I 1}$.

Dreiser, Theodore, An American Tragedy. New York: Bon1 and Liveright, $1925 .-2$ vols. $409 \mathrm{pp}$.

Dreiser, Theodore, A Book About Myself, New York: Bonl and Liveright, 1925.

Dreiser, Theodore, The Bulwark. New York: Doubleday and Company, 1945. $\overline{337} \overline{\mathrm{pp}}$

Dreiser, Theodore, Dawn. New York: Horace Liveright, 1931. $589 \mathrm{pp}$.

Dreiser, Theodore, The "Genius". New York: Bonl and Iiveright, 1923. (John Lane Company, 1915). 736 pp.

Dreiser, Theodore, Hey Rub-a-dub-dub. New York: Bonl and IIveright, $1920.320 \mathrm{pp}$.

Dreiser, Theodore, A Hoosier Hollday. New York: John Lane Company, 1916. I916. $\mathrm{pp} .513$.

Dreiser, Theodore, Life, Art and America. New York: The Diamond Press, 1917. $27 \mathrm{pp}$.

Hartwick, Harry, The Foreground of American Fiction. New York: American Book Company, 1934. pp. 85-110.

Hatcher, Harlan, Creating the American Novel. New York: Farrar and Rinehart, 1955. $\mathrm{pp} \cdot 34-58$.

Mencken, H. I., A Book of Prefaces. New York: Alfred A. Knopf, 1917. pp. 65-150.

Parrington, Vernon Louis, Main Currents in American Thought. New York: Harcourt, Brace and Company, Vol. 111, 1930. pp. 189-192, 316-319, 355-359. 
Rascoe, Burton, Theodore Dreiser. New York: Robert M. McBride, 1925. pp.I-90.

Sherman, Stuart P., On Contemporary Iiterature. New York: Henry Holt and Company, 1917. pp.134-145.

Whipple, T. K., Spokesmen. New York: D. Appleton and Company, 1928. pp. T0-93.

\section{B. PERIODICAL ARTICLES}

Dreiser, Theodore, "What I Believe", The Forum, vol. LXXXIl (November, 1929). pp. 279-281, 217-320.

$$
\text { C. NEWSPAPERS }
$$

News item in the New York Herald Tribune, March 24, 1946, "In the Large Stream of American Tradition", pp. 1-2. 